\title{
Jesus, Mary, and Joseph as Artisans of the Heart and Home in Manuscript MPM R 35 "Vita S. Joseph beatissimae Virginis sponsi" of ca. 1600
}

\author{
Walter S. Melion
}

How and why did Catholic votaries in early seventeenth-century Antwerp allegorise the relation between the material circumstances and spiritual properties of the vita Christi? And how was this relation analogised to that between public and private zones of devotion? These questions prove crucial to our understanding of manuscript MPM R 35 Vita S. Joseph beatissimae Virginis sponsi patriarcharum maximi iconibus delineata ac versiculis ornata (Life of St. Joseph, Husband of the Most Blessed Virgin, Greatest of the Patriarchs, Portrayed in Images and Ornamented with Verses), a small octavo volume housed in the printroom of the Plantin Moretus Museum [Figs. 15.1-15.24]. The book consists of forty-six engraved images comprising two complete print series: the Vita S. Joseph [Figs. 15.1-15.5, 15.19-15.24], published and engraved by Theodoor Galle, perhaps with the assistance of his brother Cornelis and/or his son Jan, and the Cor Iesu amanti sacrum (Heart of Jesus Sacred to the Loving Votary or, alternatively, Heart Sacred to the Loving Votary of Jesus), designed, engraved, and published by Antoon II Wierix before 16o4 [Figs. 15.6-15.18]. ${ }^{1}$

1 The book has three divisions: 16 prints from Theodoor Galle's Vita S. Ioseph beatissimae Virginis sponsi patriarcharum maximi; the title-print of Antoon Wierix's Cor Iesu amanti sacrum, followed by this series' 17 prints; the title-print, dedication print, and ten additional prints from Galle's Vita S. Ioseph. On the Vita S. Ioseph, see Galle Th., "The Life of the Virgin and St. Joseph", in Hollstein F.W.H., Etchings, Engravings, and Woodcuts, ca. 1450-1700, vol. 7 (Amsterdam: n.d.) 84, nos. 85-112 (28 plates). On the Cor Iesu amanti sacrum, see van Ruyven-Zeman S. - Leesberg M. (comps.), Hollstein's Dutch and Flemish Etchings, Engravings, and Woodcuts, 1450-1700, vol. 61: The Wierix Family, part 3 (Rotterdam: 2003) 44-54, nos. 445-462. The compilers date the series toward the late sixteenth or early seventeenth century, noting that the 'sequence of the plates is unknown', and the 'order of the plates used as book illustrations is differing' (44). On the cult of Joseph as father, husband, artisan, and contemplative, see McGuire B.P., "Becoming a Father and a Husband: St. Joseph in Bernard of Clairvaux and Jean Gerson", in Chorpenning J., o.s.F.s. (ed.), Joseph of Nazareth through the Centuries (Philadelphia, PA: 2011) 49-61; Chorpenning J., "St. Joseph as Guardian Angel, Artisan, and Contemplative: Christophorus Blancus's Engravings for the Summary of the Excellencies of St. Joseph (1597)", in ibidem 103-136; and Faesen R., S.J., "The Grand Silence of St. Joseph: Devotion to St. Joseph and the Seventeenth-Century Crisis of Mysticism in the 


\section{Flemish Devotional Imagery of the Heart, the Society of Jesus, and the Spiritual Exercises}

To begin, it may be useful to observe that devotional imagery focusing on the heart or, more specifically, on the human's heart's relation to the sacred heart of Jesus, became increasingly popular in Antwerp after its reconquest by Catholic forces, led by Alessandro Farnese, in July 1585. The reform orders that streamed back into the city, in particular the Discalced Carmelytes and the Society of Jesus, were largely responsible for disseminating this imagery, which derives from such biblical passages as Matthew 6:21 and 15:18-19, 1 Corinthians 2:9-10, and Romans 2:29. Together, these passages identify the heart as the place where the Spirit of God dwells in potentia and, if properly seen and heard, communicates truths 'that the [terrestrial] eye hath not seen, nor ear heard', revealing them to the 'spirit of man':

But, as it is written: [Psalm 93:11] '[...] neither hath it entered into the heart of man, what things God hath prepared for them that love him.

But to us God hath revealed them, by his Spirit. For the Spirit searcheth all things, yea, the deep things of God'?

In addition, Romans 2:29 crucially states that the human heart is amenable to penitential reformation: the penitent votary grows closer to God when s/he eschews mere circumcision of the flesh, instead embracing circumcision of the heart, cutting away its ties to terrestrial things and fortifying its links to the spiritual things of God, so that the human spirit and the divine Spirit

Jesuit Order", in ibidem 137-15o. On Jesuit devotion to St. Joseph as patron of the Society's Casa dei Catecumeni and Arciconfraternità di S. Giuseppe, see Lazar L.G., "Bringing God to the People: Jesuit Confraternities in Italy in the Mid-Sixteenth Century", Confraternitas 7.1 (1996) 11-13; idem, "The First Jesuit Confraternities and Marginalized Groups in Sixteenth-Century Rome", in Terpstra N. (ed.), The Politics of Ritual Kinship: Confraternities and Social Order in Early Modern Italy (Cambridge - New York - Melbourne: 200o) 132-149; and idem, Working in the Vineyard of the Lord: Jesuit Confraternities in Early Modern Italy (Toronto - Buffalo London: 2005) 31, 99-124. On Joseph as chief witness of the mystery of the Incarnation, see Solà F. de P., S.J., "San José en Francisco Suárez", Cahiers de Joséphologies 25 (1977) 237-251; idem, "Josefología del P. Alonso Ezquerra, S.J. (1555-1637)", Cahiers de Joséphologie 29 (1981) 210-237; and Gauthier R., C.s.C., "Saint Joseph aux Pays-Bas espagnols au début du XVII siècle", in ibidem 870-896.

21 Corinthians 2:9-10, in Challoner R. (ed.), Douay-Rheims The Holy Bible (Fitzwilliam, NH: 2013). Also see 1 Corinthians 2:11-12: 'For what man knoweth the things of a man, but the spirit of a man that is in him? So the things also that are of God, no man knoweth, but the Spirit of God. Now, we have received not the spirit of this world, but the Spirit that is of God: that we may know the things that are given us from God'. 
become one, virtually identical. The notion that the heart's spiritual resemblance to Christ can be actively cultivated, that the heart can be moulded in his image, derives from the dynamic conception of the heart codified by Aristotle and Galen who respectively described it as the seat of intelligence, motion, and sensation, and the physical organ most closely related to the soul.

Ignatius of Loyola's Spiritual Exercises, first published in 1548 and republished with extensive supplementary directives in 1599, may best be construed as a meditative program designed to bring the exercitant's heart more fully into alignment with Christ by activating that most complex of sensations - human emotions. Here, for example, is what the directory says about energising the heart during the third week of the Exercises, which dwells on the form, function, and meaning of the Passion of Christ:

It will also be of assistance to have at hand during this week some sentences of sacred Scripture pertaining to the Lord's passion, from the Psalms, or the Prophets, especially Isaiah, or the Gospels, or the Epistles of Paul, which will reveal the magnitude of the sorrows and torments of Christ the Lord, or of his goodness, or of the miracles [he] effected for the reparation of men; all this will be beneficial not only for meditation but very much, too, for excitation of the heart, and also for rooting out a certain feeling of satiety that is wont to set in from the continuation of these same things. ${ }^{3}$

Although the Spiritual Exercises were supervised by a director, they were designed, like other kinds of meditative prayer, for the express purpose of promoting one-to-one contact between the soul and Christ, in a form as direct and unmediated as possible. Each person was given the opportunity of finding a pathway to God and journeying along it. The Jesuits conceived of the ensuing journey as that person's house or vocation, a private locus of spiritual intercourse encompassing the Lord's and the exercitant's hearts, in tandem

3 Exercitia spiritualia S.P. Ignatii Loyolae, cum sensu eorumdem explanato (Antwerp, Typis Henrici Trieullier: 1696) 78: 'Juvat etiam habere in promptu hac hebdomada aliquas sententias sacrae Scripturae, ad Domini passionem pertinentes, ex psalmis, vel ex Prophetis, et maxime ex Isaia, vel etiam ex Evangeliis, aut ex epistolis Pauli; quae vel magnitudinem dolorum ac cruciatuum Christi Domini indicent, et ejus bonitatem, aut effectus mirabiles in hominum reparatione, quae extra meditationem valde proderunt ad cor excitandum, et etiam ad tollendam nescio quam satietatem, quae subrepere solet ex continuatione earumdum rerum'. 
or in communione. ${ }^{4}$ Indeed, it might be truer to say that just as the Spiritual Exercises, in all four weeks, focus on conversion of the exercitant's heart into a habitatio Iesu, so, too, the private, notionally cordiform space that meditative prayer opens up, is a house neither static nor fixed but mobile. Its foundations and walls fluctuate as the votary's spiritual condition fluctuates, becoming stronger or weaker, more opaque or transparent to Christ, as s/he comes closer or goes farther from him. Moreover, this private edifice of faith requires constantly to be monitored, rebuilt, refashioned, as supervenient and efficient grace allow, and the spiritual agency of the votary permits. Jesuit meditative culture shares many features, mutatis mutandis, with that of the other reform orders that intensively proselytised and ministered within and beyond the precincts of Antwerp and its religious houses, confraternities, and schools. The manuscript to which we shall now turn is a precious relic of the heartbased prayer propagated at the Jesuit College of Antwerp. Remarkably, it gives access to the private domain of one specific heart, and reveals how that heart labored to enter fully into the loving heart of Jesus, and to be entered by him.

\section{Theodoor Galle's Life of Saint Joseph Becomes a Jesuit Prayerbook}

The Vita S. Ioseph includes a dedication plate that functions like a frontispiece, addressed to the 'Most Serene Isabella Clara Eugenia, Infanta of the Spaniards, Regent of the Belgians, Most Devout Votaress of the Most Holy Saint Joseph'; the epigraph is signed 'Theodoor Galle most willingly offered this most deservéd gift, the Life of the Great Patriarch, illustrated with images' [Fig. 15.20]. ${ }^{5}$ The Cor Iesu is a first edition, printed before the addition of numbers at the lower right, and the dedicatory text identifies the Archduchess, who ruled between 1601 and 1633, abdicating in that latter year, as still 'proregina', sovereign of the Spanish Netherlands [Figs. 15.6-15.18]. These circumstantial details indicate

4 On Ignatius's adherence to the general confession of devotion, as codified in the Devotio Moderna, and on his ultimate goal of converting the heart through the exercise of graces stemming from the sacrament of Penance, see O'Malley J.W., S.J., "Some Distinctive Characteristics of Jesuit Spirituality in the Sixteenth Century", in idem, Saints or Devils Incarnate? Studies in Jesuit History (Leiden - Boston: 2013) 165-180; and, on the Jesuit notion that journeying in service to Christ and the Church is a kind of house (complementary to the novitiate and professed houses and to the schools), experienced privately in and through the heart, and exercised publicly through ministry, see idem, "To Travel to any Part of the World: Jerónimo Nadal and the Jesuit Vocation", in ibidem 147-164.

5 Plate 36; 'Serenissimae Isabellae Clarae Eugeniae Hispaniarum infanti Belgarum proreginae, Sanctiss. Ioseph cultrici piissimae, Theodorus Galleus magni patriarchae vitam iconibus illustratam mer. Lib. DD'. All translations are mine. 
that the manuscript may have been compiled between 1601 and 1633, possibly as early as $1601-1604$. Since the prints were neither cut nor pasted in, as was typical of manuscript libri precum (books of [meditative] prayer) and gebedenboeken (prayer books) organised around printed images, and the bound sheets have uniformly large margins, on which the texts in Dutch were handwritten, it seems likely that the two series were acquired with a view to assembly into a prayer book with interpolated gebeden (prayers). The images were expertly and lavishly illuminated, with a wide range of colours applied semi-transparently, leaving the line-work legible and, in places, enhancing it. In addition, numerous details, such as haloes and the fringes of garments, were gilt. The result is a work of mixed genre, part print series, part printed book, part manuscript, the whole resembling an illuminated liber precum or gebedenboek.

The book's owner was most likely the young man who signed fol. 34r, the final print in the Cor Iesu sequence, showing the votary's heart, fully and lovingly consonant with the heart of Jesus, being crowned by the Lord himself, in the presence of God the Father, as if it were the heart of Sponsa, the bridegroom's spiritual bride, or of a triumphant martyr, or again, of the Virgin Mary, Queen of Heaven [Fig. 15.18]. Below the two verses in Dutch and the Jesuit motto 'Ad maiorem dei gloriam', Marinus van Heule identifies himself as scribe ('schripsit') and as 'sintaxianus', a student of syntax in the Jesuit college of Onze Lieve Vrouw (Our Lady) in Antwerp. ${ }^{6}$ The notion that one's heart can be wed to the heart of Jesus, or again, that the anima (soul) is the sponsa (bride) of Christ who is the soul's true sponsus (bridegroom), derives from patristic reading of the Parable of the Wise and Foolish Virgins (Matthew 25:1-13) codified in the Glossa ordinaria, as well as from Bernard of Clairvaux's Sermons on the Song of Songs, in which The Canticle is read as a nuptial allegory of the soul's marriage to Christ. Although Bernard addressed his sermons to his Cistercian and Benedictine brethren, they were disseminated more widely in the Rhineland and Low Countries, not only amongst the clergy but also the laity, by the mystic theologian Jan van Ruusbroec, by Carthusian authors, and, later and most importantly, by adherents to the Devotio moderna such as Geert Groote, cofounder of the Brethren of the Common Life. ${ }^{7}$

6 'Schripsit marinus van heule sintaxianus'.

7 On Jan van Ruusbroec and the dissemination of his writings amongst clergy and laity in the Low Countries, see Warnar G., Ruusbroec: Literature and Mysticism in the Fourteenth Century (Leiden: 2007); van Nieuwenhove R., "Ruusbroec, Jordaens, and Herp on the Common Life: The Transformation of a Spiritual Ideal”, in Arblaster J. - Faesen R.S.J. (eds.), A Companion to John of Ruusbroec (Leiden - Boston: 2014) 204-236; and idem, "Catholic Piety from Ruusbroec and the Devotio Moderna to the Legacy of Pierre de Bérulle", in Ayres L. - Volpe M.A. (eds.), The Oxford Handbook of Catholic Theology (Oxford: 2019) 577-594, esp. 577-584. 
Midway through Galle's Vita S. Joseph - at the book's heart, one might say Van Heule interpolated Wierix's Cor Iesu [Fig. 15.6-15.18]. Embedded within the Vita's scenes of the domestic life of the boy Jesus, who learns from Mary and Joseph how to handle household utensils and the implements of the workshop, the Cor Iesu describes various stages in the practice of mystical devotion, showing how Jesus comes gradually to dwell within the human soul, finally uniting with the votary, whose heart becomes indistinguishable from his own. ${ }^{8}$ The latter series thus becomes a serial image of Joseph's heart, illustrating the nature and scope of his contemplative devotion to Jesus. Whereas in the Vita S. Joseph, Joseph teaches his foster son how to master the carpenter's materials and tools [Figs. 15.22 and 15.24], in the Cor Iesu Jesus takes the lead, teaching his foster father how to conform his heart to that of his Saviour [Figs. 15.7-15.18]. The space of the former series is public or semi-public - the streets and temple of Bethlehem, the stable open to the elements and visited by the shepherds and Magi, the household cum workshop in Nazareth; the space of the Cor Iesu is insular, closed to worldly temptations, transported heavenward, transparent only to angels, and solely accessible to the boy Christ, whose boyhood alludes to the fact that he is visiting his father's loving heart. The two spaces are mutually defining. The descriptive imagery of the Vita S. Joseph leads directly to the allegorical imagery of the Cor Iesu, wherein Jesus is seen to penetrate Joseph's heart, both materially and spiritually, in corpore et spiritu. Conversely, the symbolic allegory of the heart infuses or, better, saturates the scenography of the Vita S. Joseph, inviting the reader-viewer to construe its images as allusions to the heartfelt relation shared by Mary, Jesus, and Joseph, a relation mutually signified through their familial activities as loving father, mother, and son. In this scenario, familiarity with material things stands proxy for the heart's familiarity with Jesus; the artisan Joseph, in concert with Mary, passes on his manual skills, and mutatis mutandis, Jesus skillfully fashions his father's heart into a spiritual home and workshop within which he comes eternally to dwell. The events and circumstances narrated in the first series enframe the embedded allegorical series, which then redounds upon the framing images, converting them into allegories of a sort, so that two registers of allegory - and of materiality, that of artisanal things and that of the corporeal heart - can be seen to interact.

The manuscript opens with sixteen plates from the Vita S. Joseph: the sequence takes the reader-viewer from the betrothal of Mary and Joseph to the Rest on the Flight into Egypt [Figs. 15.1-15.5]. Next come the title-print and

8 The Cor Iesu amanti sacrum is unnumbered, and owners of the series could thus exercise considerable latitude in how they ordered the prints. 
seventeen plates from the Cor Iesu [Fig. 15.6-15.18]. After the closing plate of the Cor Iesu, "Christ Crowns the Loving Heart" [Fig. 15.18], the reader-viewer reenters Galle's Vita S. Joseph: first come the title-print, the dedication page, and "In caelis gloriosa sessio" (Glorious Seat in Heaven), an affirmation of Joseph's heavenly rank and station [Figs. 15.19-15.21]; the vita then re-commences with the life of the Holy Family in Egypt, their return to Nazareth at Christ's behest, and his tutelage at home and in the workshop (as portrayed here, the two are one and the same) under the watchful eyes of Mary and Joseph [Figs. 15.22-15.24].

\section{Wierix's Heart of Jesus as the Heart of Joseph}

The most conspicuous of the alterations to Galle's series was the decision to interrupt it sixteen plates into the cycle of twenty-eight. After "Nocturna hospitatio", he inserts the Cor Iesu amanti sacrum [Figs. 15.5 and 15.6]. The point of transition lies in what this plate shows [Fig. 15.5]: en route to Egypt, the Virgin suckles the infant Jesus, holding him close to her heart; Joseph responds in kind, though more humbly, provisioning their mule, in imitation of Mary whom he sees feeding their son: 'Gently as she gives suck to the child, so Joseph takes the mule in hand, rejoicing in his service. ${ }^{9}$ The title-print of the Cor Iesu that immediately follows depicts male and female members of various religious orders, including a Capuchin and a Jesuit, labouring to sustain a heart lovingly aflame [Fig. 15.6]. This is the votary's heart, 'sacred to the loving Jesus', in one possible reading of the titular text; but, in an alternative reading, it is also the Lord's heart, 'sacred to the lover of Jesus'. The Dutch text, 'Het herte is heilich dat Godt bemint', further ambiguates the heart's identity: it can equally be read as, 'The heart that loves God is holy', or, 'The heart that God loves is holy' The Cor Iesu series, then, purports to tell the story of the heart of Jesus nourished by the votary, as Jesus was nourished by Mary, or the story of the votary's heart nourished by Jesus, as he spiritually nourished his mother even as she sustained him bodily. More precisely, it tells the story of the relation between the heart of Jesus and that of Joseph, which, as the series progresses, become virtually indistinguishable. Underlying this history of Joseph's heartful imitatio Christi, is his loving imitation of the Virgin, as exemplified in "Nocturna hospitatio". The hospitatio, the place that offers hospitality, is by turns Jesus's

9 'Blande natum quando lactat,

Et iumentum Ioseph tractat

Gaudens ministerio'. 
heart and Joseph's. The heart, thus conceived, constitutes a zone of privacy so personalised, so removed from public discourse and social exchange, that self and other, ego and ille coalesce, becoming veritably indistinguishable. The implicit presence of Mary suggests that she too is gathered up into this mystical space of coalescence.

Tellingly, the mid-point of the Cor Iesu, in the order wherein it here appears, eight plates from the beginning [Fig. 15.7], and eight from the end [Fig. 15.18], is the plate showing Christ as a painter, brush and palette in hand, portraying the Four Last Things - Death, Judgment, Salvation, and Damnation [Fig. 15.11].10 The image of the heart as a painter's panel and a workshop becomes the series' crucial turning point: after "Christ Paints the Four Last Things", it is the heart variously transformed in the image of Christ that is portrayed. The transfer of hearts becomes far more pronounced, leading ultimately to the elision of the hearts of Jesus and the votary, or rather, of Jesus and Joseph, who functions as a surrogate for the votary throughout the Cor Iesu. In "Christ Garlands the Heart, Strewing it with Flowers", for example, the heart is either Christ's or the votary's [Fig. 15.13]; the Latin verses equivocate, simply urging Jesus to augment the heart's efflorescence: 'Bravo, lad! Embroider with roses now this side, now that, encompass them. Wreath the little heart, all of it. // Strew it with the progeny of the springtime dew, with the whole harvest of Chloris: spread for yourself a [flowery] bed.'1 In the last plate, "Christ Crowns the Loving Heart and Adorns It with Palm Fronds", the heart's door is closed, for the heart has become whole and entire [Fig. 15.18]. The ceremony of crowning is either a kind of self-apotheosis jointly effected by the Son and the Father (as witness the radiant tetragrammaton hovering above the heart), or Jesus's crowning of his sovereign queen, more precisely, of the spousal heart of his well-loved and loving bride.

The Cor Iesu amanti sacrum is replete with references to Jesus as an artisan who labours assiduously to transform the human heart, striving to bring about its conformation to his own heart. In "Christ Paints the Four Last Things", for instance, the tools which the Latin tercets exhort him to take up are a painter's

10 After the title-print, eight prints follow, then the plate with Christ as painter, which is then followed by eight additional prints; "Christ Paints the Four Last Things", in this ordering of the series, may thus be seen as the pivotal plate around which the others cluster.

11 'Euge puer, rosis pinge,

Latus hoc, et illud cinge,

Totum cinge corculum. //

Sparge foetus verni roris,

Sparge totam messsem Chloris:

Sternis tibi lectulum' 
pigments and implements [Fig. 15.11]: 'Jesus, grab hold of the little brushes, and dab holy images onto all of the heart'.12 His brushstrokes will efface the idle phantasms that merely stain the heart ('inquinabit'), having been applied by Desire, companion to Venus: 'Thus will Venus not profane it, nor desire stain it with with vain phantasms.13 The Dutch text asks him to fill the whole heart with godly little images applied with small brushes. ${ }^{14}$ The many allusions to artisanal skill and manual expertise anticipate the final section of the prayerbook. The coalescence of the two hearts whose gradual merger the Cor Iesu tracks is replayed in the register of artisanship when one re-enters Galle's print series. Joseph and Jesus are recognised as fellows in craft, becoming increasingly the same, as the master artisan / foster father passes on his skills to his chief apprentice / foster son. What the Cor Iesu reveals, however, is that Christ, even before he is apprenticed to Joseph, already qualifies as a master artisan; his workshop is the heart, both his own and his father's, which halfway through the series he transforms into a painter's atelier ("Christ Paints the Four Last Things"), into a builder's workplace ("Christ Fashions the Arma Christi"), into a florist's studio ("Christ Garlands the Heart"), reversing the relation between master and apprentice [Figs. 15.11, 15.12, and 15.13]. The mystery of the Incarnation, Christ the Word's humbling of himself in the flesh, and conversely, his elevation and sanctification of that flesh, thus plays out on the level of artisanship, in the shifting relation between Jesus and Joseph, by turns master and apprentice, apprentice and master.

\footnotetext{
12 I have translated 'conscribillare' as 'dab' to align it with the reference to 'penicilla', but the term can also signify 'to mark with lines' and, as such, would constitute a meta-reference to Wierix's print[s]. My thanks to Lars Cyril Nørgaard for calling this usage to my attention.

13 'Sume Iesu penicilla, Corque totum conscribilla Pijs imaginibus: // Sic nec Venus prophanabit, Nec Voluptas inquinabit Vanis phantasmatibus'.

14 'Nempt toch iesus het pinselen en beschrift gheel het herte met godtvruchtege beldekens. het 2 deel alsoo noch venus prophinasert noch de wellusten besmet met Idele ghepeisen'.
} 
In closing, I want briefly to examine Jerónimo Gracián's Summario de las excelencias del glorioso S. Joseph, esposo de la Virgen María (Summary of the excellences/merits of the glorious saint Jospeh, the husband of the Virgin Mary), one of the treatises on which Marinus van Heule likely drew in assembling and inscribing his prayer book..$^{15}$ Gracián's treatise was largely responsible for cementing Joseph's reputation as the saint who, after Mary, most fully harmonised the active and the contemplative lives. Written for the laity and widely read, it would certainly have been well known in the Spanish Netherlands; moreover, as I hope to show, Galle's iconography, his emphasis on Joseph's artisanal virtue in particular, jibes in every respect with Gracián's account. The Summario lauds Joseph for his dual competencies: a superbly skilled faber (joiner, forger, carpenter, builder), he met his family's every material need, building the house where they dwelt, forging its nails and locks, and furnishing it; an equally skilled votary, he daily engaged in prayer and other spiritual works, striving to build another kind of house for Christ, who thus took up residence in Joseph's heart and soul. Jointly exercised, his active and contemplative abilities prove entirely compatible: he is as much a faber of the heart, as a worker of wood, and his spiritual exercises fuel his good works. Gracián compares him initially to Martha, sister of the Magdalene, who was 'anxious, solicitous, and troubled by many things' when Christ called upon them (Luke 10:38-42); so too, the Virgin's straitened circumstances and the extreme poverty into which Christ was born, greatly perturbed Joseph:

15 Gracián Gerónimo, Summario de las excelencias del glorioso S. Ioseph, esposo de la Virgen Maria (Rome, Antonio Zannetti: 1597) 120-121: ‘[... y en ninguno se hallo la fee, oracion, mortificacion, piedad y mitacion de Christo, y charidad en mas alto grado que en ellos, es cierto que en ninguno se hallaria en mas alto grado la union con Dios que en Maria, y Ioseph. On Gracián and the Summario, see Allison Peers E., Studies of the Spanish Mystics, vol. 2 (London: 1927-196o) 151-189; Moriones I., "Jérome de la Mère de Dieu", in de Guibert J., S.J. - Viller M. - Cavallera F. (eds.), Dictionnaire de spiritualité, vol. 8 (Paris: 1974) cols. 920-928; Carrasco J.A., "Fray Jerónimo Gracián de la Madre de Dios y su Summario de las excelencias del glorioso S. Joseph, esposo de la Virgen Maria o Josefina", Cahiers de Joséphologie 25 (1977) 295-322; Pacho E., "Jerónimo Gracián de la Madre de Dios: vida y obra", in Pacho E. (ed.), El Padre Gracián: Discípulo, amigo, provincial de Santa Teresa (Burgos: 1984) 7-57; Lorenz E., "A Carmelite in Slavery: Father Gracián, Friend of Teresa of Jesus", Mount Carmel 35 (1987) 51-63; and Chorpenning J., o.s.F.s., "Introduction", in Chorpenning J., (ed.), Just Man, Husband of Mary, Guardian of Christ: An Anthology of Readings from Jerónimo Gracián's Summary of the Excellences of St. Joseph (1597) (Philadelphia, PA: 1993) 1-64. 
Tell me, who has ever read that a man faithful, discreet, and of noble birth would desire to do otherwise than provide hospitality if his legitimate king, with whose great majesty he was acquainted, and from whom he hoped for every remedy, were to visit his house? What [would he feel] if he had no bed in which to lay him down, no place of refuge, were such a king to come calling in great need? ${ }^{6}$

Whereas the first third of Van Heule's prayerbook, plates 2-16, focusing on the infant Christ, characterises Joseph as a man heavily burdened by the cares of fatherhood, the next third of the prayerbook, comprising the eighteen plates of the Cor Iesu amanti sacrum, might best be described as showing how Joseph, formerly likened to Martha, now becomes more like her sister Mary, whose prayerful attention Christ praises in Luke 10:42, and whom exegetical tradition identified as Mary Magdalene: 'Mary hath chosen the best part, which shall not be taken away from her'. As the first third of the prayerbook concludes with the journey into Egypt, so plate 18 initiates the spiritual journey to be undertaken by Joseph: the child Jesus embraces his foster father's heart, shielding it from the personifications of worldly cares and temptations round about [Fig. 15.7]. The Latin verses counsel this heart to identify with the heart of Christ ('Christi sinus') wherein it may shelter from the importunate world. The tercets turn on the term sinus (heart, but also hiding place or place of refuge): "The false world adorns [her] face; fraud conceals in order to deceive. Trust not her blandishments. If you wish to escape the net, seek the heart of Christ, far from snares.' ${ }^{17}$ The subsequent sixteen plates chronicle the steps taken by Jesus in concert with the heart, as they become increasingly alike and, finally, indistinguishable. This point is reached in plate 33, which portrays Christ standing within Joseph's fiery, loving heart, and offering him his own heart, equally aflame [Fig. 15.17]. Fiery with the love of Jesus, Joseph's heart subsumes Jesus; by the same token, Jesus proffers his heart fiery with the love of Joseph. The Latin verses simultaneously address both hearts, emphasising that they have

16 Gracián, Summario 189-19o: 'Digame quien esto leyere, que sentiria un hombre piadoso, discrete, y noble de condicion, si viniesse a sus casa su natural Rei, de quien conosciesse grandeza de Magestad, y esperasse todo su remedio, sino tuviesse con que hospedalle? $\mathrm{Ni}$ cama en que le acostan, y el Rey viniesse tan necessitado, que en otra parte no tuviesse refugio'.

17 'Fallax mundus ornat vultus,

Dolus latet sed occultus:

Ne crede blanditijs - //

Hoc vitare si vis rete;

Cito Christi sinus pete

Procul ab insidijs'. 
become one and the same: 'Behold, Jesus extends his hands armed with flames, ignites the heart with firebrands on this side and on that. Come! Let the heart be consumed; let it be reduced to ash by the fires of love.' ${ }^{18}$

The interior journey extending from plates 19 to 33 closely follows that described by Gracián in chapter 3 of book III, "On the perfection of Joseph's soul, [in which] is declared that perfection is the union of the soul with Christ; the differences and component parts of the union are adduced, and how Joseph was excellent in all these". ${ }^{19}$ Viewed through the lens of Gracián, the Cor Iesu amanti sacrum can be said to track the growing perfection of Joseph's heart as it approaches the 'summit of charity' ('cumbre de la charidad'), becoming a kind of living oratory ('paradero de los exercitios de oracion', i.e., a dwellingplace for spiritual exercises), wherein true perfection, which is the 'union between God and the soul' ('perfection es union entre Dios, y el alma'), may be discerned..$^{20}$ The means to perfection, says Gracián, is prayer ('el principio de toda la perfection es la oracion'), and the Cor Iesu amanti sacrum demonstrates how Joseph achieves spiritual perfection through his heart's contemplative engagement with Jesus. ${ }^{21}$ Plate 33 , the series' penultimate episode, exemplifies Gracián's conviction that 'unity [...] is the aim of all contemplation', through which the 'votary binds his works to Christ, who is their true source, attaching him interiorly to the soul as its first principle, final end, and the means to that end. ${ }^{22}$

The prayerbook's first part, plates 1-16, concludes with "Nocturna hospitatio" (Nocturnal Lodging), in which Joseph sets about the task of feeding the family's pack animals [Fig. 15.5]. Plate 19 answers this plate, both as complement and antithesis: posed like Joseph (though turned 180 degrees), and placed like him at the threshold of a dwelling (though outside), Jesus knocks at the door of his foster father's heart, urging him to set aside his many pressing concerns; he should instead listen to the gentle beating of the cor Iesu [Fig. 15.8]:

18 'En armatas flammis tendit

Iesus manus, cor accendit

Hinc et illinc facibus. //

Age, totum comburatur,

In favillam redigatur

Cor amoris ignibus'.

19 Gracián, Summario 117: "De la perfecion del alma de Ioseph: declarase que la perfecion es union del alma con Christo: ponense las differencias, y partes de la Union, y como en todas ellas fue aventajado Ioseph".

$20 \quad$ Ibidem $117-118$.

21 Ibidem 118.

22 Ibidem 119: '[...] la unidad, por que esta es el fin de toda la contemplacion [...] que contemplando llegan a juntar sus obras, con el primer principio, y juntando dentro de su anima el principio, fin, y medio, hazen de todo una cosa dentro de si'. 
Outside, Jesus knocks at the door of the heart, falls silent, and listens to his little heart's voice.

Arise, heart, undo the bolt: what need is there for action; [instead] meditate the advent of the little bridegroom. ${ }^{23}$

Jesus further resembles Joseph as he appears in plate 8, "Hospitii perquisitio" ("Search for Lodging"), poised at the threshold of the inn, and plate 9, "Sponsae Virginis parturitio" ("Parturition of the Virgin Bride"), where he bends over the newborn Christ, one arm raised, the other lowered [Figs. 15.2 and 15.3]. These similarities illustrate the first of the five kinds of union leading by degrees to complete oneness with Christ, enumerated by Gracián in chapter 3 of book III: 'The mystical theologians treating of the union between one and another thing put forward five constituent parts. The first they call unio similitudinis, which is to say, union of likeness. ${ }^{24}$

Once Christ enters Joseph's heart, lighting its innermost recesses (plate 20), emptying them of worldly things (plate 21), washing them with his blood (plate 22), and purifying them, he effects the second degree of union - unio propinquitatis - the union of propinquity, when two things are made adjacent and 'joined, like hands linked'.25 In plate 24, Joseph is finally transformed into the living house of God, the throne room from which Christ reigns [Fig. 15.9]. The Latin tercets aver that Jesus, working from within, effects a change in the appearance of the votary, whose face becomes as placid as the Lord's, once the cares of the world have been dispelled:

Whose face does he not make serene? Behold, Jesus holds the sceptre in the palace of the heart.

Throw open your face to Jesus alone; commend to him what you will; give to him what you commit. We are present in obedience. ${ }^{26}$

23 'Ultro cordis portam pultat

Iesus, silet, et auscultat

Vocem sui corculi. //

Cor exsurge, vectem solve:

Quid sit opus factu, volve

In adventum sponsuli'.

24 Gracián, Summario 121: 'Los Theologos misticos tratando de la union entre otras ponen cinco partes della. La primera llaman unio similitudinis, que es dezir union de semejanza, y es la que ay entre dos cosas que se parecen'.

25 Ibidem: 'La segunda, unio propinquitatis, union de cercania, quando dos cosas estan juntas una con otra, como quando dos manos se ayuntan'.

26 'Quis hic vultum non serenet?

Iesus ecce sceptra tenet

Cordis in palatio. // 
The third degree of union - unio inhaesionis - the union of adhesion, by which the things of Christ are made to stick, cleaving to the heart like wax adhering to a wall', is illustrated in plates 25 and 26 [Figs. 15.10 and 15.11 ]. ${ }^{27} \mathrm{In}$ the former, these things are the words of Holy Writ: Jesus holds open a gospel book inscribed with the passage, 'They shall be taught of God' (John 6:45: 'Erunt omnes dobiciles Dei', literally, 'They shall become apt to learn of God'). The tercet reads:

These are they who give ear to Plato, or to eloquent Cicero, or to the foolishness of the world.

Spurn not the words of life. Listen to the words of Wisdom of the eternal Father. ${ }^{28}$

In the latter, the doctrina Christi adheres in the form of images painted onto the heart by Christ himself. ${ }^{29}$

Plates 27-3o encapsulate the fourth degree of union - unio conversionis - the union of conversion, 'when two things are converted into one by virtue of heat or some other quality, in the manner of sugar and quinces, which are made into marmalade, or like any other conserves or electuaries' [Figs. 15.12-15.14]. ${ }^{30}$ In plate 27, Jesus implants the arma Christi in the heart, causing it to participate in his Passion, so that his suffering and the heart's meld, and his purity evacuates the sickness of $\sin$ [Fig. 15.12]:

Iesu tantum ora pandas

Manda quod vis, dat quod mandas:

Adsumus obsequio'.

And alternative translation would read: 'Jesus only reveal your face; command what you will; bring forth what you command. We stand ready to obey'.

27 Ibidem: 'La tercera, unio inhaesionis, que es dezir de apegamiento, o aferramiento, como quando la cera se pega a la pared'.

28 'Sunt auscultent qui Platoni,

Aut facundo Ciceroni,

Aut Mundi stultitiae. //

Tu ne verba vitae sperne:

Audi Patris aeviternae

Dicta Sapientiae'.

29 See footnotes 12 and 13 supra.

$30 \quad$ Ibidem: 'La quarta, unio conversionis, quando dos cosas por virtud del calor, o de otra calidad, se convierten en una, de la manera que del açucar, y membrillo, se haze la mermelada, o qualesquier otras conservas, o letuarios'. 
Good Jesus, fashion the cross, the scourge, the savage lance, fashion them in the basement of the heart.

No sickness shall prevail when you, with this small nosegay of myrrh, devise preservatives against disease. ${ }^{31}$

In plate 28, the roseate presence of Christ causes the heart to effloresce: wreathed with a bridal crown, the fragrant heart is conjoined with Christ, as his roseate bride [Fig. 15.13] ${ }^{32}$

The final three plates, $3^{2-34}$, reveal that Joseph has achieved the fifth and highest stage of union - unio naturalis - the union of natures like unto that which 'exists between the soul and the body whereof a human being is composed' [Figs. 15.16-15.18]. ${ }^{33}$ Plate 32 illustrates how deeply Christ has penetrated Joseph's soul; he has pierced him so thoroughly that no further wounds are possible [Fig. 15.16]. The dove of the Holy Spirit hovering above the heart's valve confirms that the heart is now saturated by divine grace: 'Enough now, Jesus, you have wounded it; enough now, with fiery arrows you have wholly penetrated it. Desire, be far, far from here: for this celestial Cupid shall conquer [bodily] fire with [spiritual] fire. ${ }^{34}$ In plate 34, God the Father, present in the form of the tetragrammaton, consecrates the loving union of Jesus and Joseph: surrounded by angels bearing palms and wreaths, the heart victorious is crowned by Christ, its royal consort and bridegroom [Fig. 15.18]:

31 'Bone Iesu conde crucem,

Virgam, lanceamque trucem, Conde in imo corculo. //

Nulla praevalebit lues,

Amuleta quando strues

Hoc myrrhae fasciculo'.

32 See page 324 and footnote 11 supra.

33 Gracián, Summario 121: 'La quinta, union natural, que se halla entre el alma, y el cuerpo de que se compone un hombre'.

34 'Sat est, Iesu, vulnerasti,

Sat est, totum penetrasti

Sagittis ardentibus. //

Procul, procul hinc libido:

Nam caelestis hic Cupido

Vincet ignes ignibus'. 
O blessed condition of Love! After so many games, so many signs of honor, so many joys,

The diadem of the kingdom is given, and the heart is adorned with plams of immortal glory. ${ }^{35}$

In effect, a marriage ceremony and coronation are jointly enacted, and the union of Jesus and Joseph is thereby doubly sanctioned. Jesus is both bridegroom and officiating priest, and Joseph is the bride, with the four angels as witnesses. Their attributes - wreaths and crossed palms - signify the triumphant felicity of the sponsus and sponsa (bridegroom and bride), whose spiritual union has vanquished every earthly vicissitude. That the interior of heart is no longer visible, its valve alone open to the Father's light, alludes to the intensely private nature of this nuptial celebration: even though Jesus would seem to be standing outside the heart, he is to be understood as fully united with it, in a spiritual sense enclosed by it. Indeed, the prior print declares that Jesus and the heart, shown engulfed by flames, have been conjoined by the power of love: he stands within it and makes an offering of his own heart, likewise aflame, which he holds in his right hand. ${ }^{36}$ The dual conflagration of heart within heart testifies to the merger of Jesus and Joseph, whose union is then sealed sacramentally in the series' final print.

The final set of twelve plates return to the public sphere of familial and artisanal labour: Joseph labours more concentratedly in Egypt, en route to Nazareth, and in the holy family's workshop home to serve and imitate Christ, in light of his heart's transformation [Figs. 15.19-15.24]. If Joseph is a signal

\footnotetext{
35 'O beata sors amoris

Post tot lusus, tot honoris

Signa, tot laetitiae, //

Diadema regni datur,

Et cor palmis exornatur

Immortalis gloriae'.

$36 \quad$ 'En armatas flammis tendit

Iesus manus, cor accendit

Hinc et illinc facibus. //

Age, totum comburatur,

In favillam redigatur

Cor amoris ignibus'.

'Behold, Jesus extends his hands armed with flames, ignites the heart with firebrands on this side and on that. Come! Let the heart be consumed; let it be reduced to ash by the fires of love'.
} 
contemplative, he is also an exceptional artisan, as Gracián asserts in chapter 5 of book II, "On the mystery to be inferred from Joseph's having been a carpenter, and from Jesus having exercised the same office, and on that which we owe this saint for having been instructed by Christ about the fabric of the Catholic Church; in which [chapter] are advanced some praises of the art of carpentry" ${ }^{37}$ Here he argues that the fabrica (builder's art) practised by Joseph and Jesus was both material and spiritual. Their efforts in the workshop were an earnest - a token, promise, or assurance - of the finer art of fabricating human hearts (he uses the term consciencias) into a place of habitation where divine love, bodied forth by Christ, can take up residence and flourish. ${ }^{38}$ It is as if Gracián were describing the relation between the workshop scenes in the Vita S. Joseph and the scenes of Christ refashioning Joseph's heart into a suitable habitation for himself in the Cor Iesu amanti sacrum. The two series thus entwine into an ingenious chiasmus: in the Vita S. Joseph, it is Joseph who teaches carpentry to Christ in the semi-public sphere of the artisanal home [Figs. 15.22 and 15.24]; in the intensely private sphere of the Cor Iesu amanti sacrum, it is Christ who rebuilds Joseph's heart from within [Figs. 15.7-15.18]:

In the first book, I put forward five admonitions whereby the soul can be married to grace by means of penitence; in this second [book], I shall adduce five others, to teach the art of fashioning a habitation for divine love in our consciences: wherefore we have declared that Joseph was a carpenter, and Jesus, the son of the builder of the world, exercised the office of carpentry, and said that he who loves him shall keep his commandments, and God shall dwell in his heart [John 14:15 and 14:23]; I wish to teach in five rules the art of labouring over your conscience, so that it may be a pleasant and worthy dwelling place of God, and a receptable of charity. ${ }^{39}$

37 Gracián, Summario 78: "Del misterio que se colige en haver sido S. Ioseph carpintero, y que el mesmo officio exercito Iesus, y lo que devemos a este Sancto, por haver Christo comunicado con el la fabrica de la Yglesia Catholica. Ponense algunas alabanças del arte de Carpinteria".

38 Gracián, Summario 86-9o, esp. 86.

39 Ibidem, 86: 'En el primer libro puse cinco avisos, con que se puede desposar el alma con la gracia mediante la penitentia, en este segundo pondre otros cinco para enseñar el arte, con que se fabrica la morada del amor de Dios en nuestras consciencias: que pues hemos declarado que S. Iospeh fue carpintero, y Iesus hijo del fabricador del mundo uso el officio 
Extending the analogy between carpentry and soul-formation, Gracián invites his readers to mark the board of conscience and the beam of the heart with the red-chalked cord of knowledge, to make straight the edges of good propositions, and to square all that one does, justifying it with the plumb, compass, and ruler. One must make use of 'el compas de la consideracion' ('the compass of consideration'), of 'el cartabon de la rectitud, y la esquadra de la conformidad a la ley divina' ('the square of rectitude and of conformation to the divine law'). With 'la sierra de la palabra de Dios' ('the saw of the word of God'), the soul must be purified, made even and level. Through the practice of virtue, the heart is set upon 'el banco de la rectitud' ('the workbench of rectitude') fixed in 'el barleto de la verdad' ('the holdfast of truth'), and worked with 'la juntera de la prudencia, escofina de la templança, y grafil de la fortaleze, [...] la gubia del rendimiento, y todos los demas hierros de hazer cornijas' ('the plane of prudence, the rasp of temperance, the graver of fortitude, the gouge of submission, and other tools for crafting ornaments such as mouldings') ${ }^{40}$ Gracián's ingenious alignment of two species of artisanal imagery - of the

de carpinteria, y el dize que "el que le ama guardara sus mandamientos, y Dios morara en su coraçon"; quiero os enseñar con cinco reglas el arte de labrar vuestra consciencia, para que sea agradable, y digna morada de Dios, y receptaculo de la charidad'.

The full text of the passage, in ibidem, $86-87$, reads: '[...] tome la cartilla, o deprenda donde se enseña, y lleve la guarda de la ley por regla, y nivel en todas sus actiones, heche el cordel de almagrar del conoscimiento sobre la tabla de su consciencia, y madero de su coraçon, para hazer derechos los filos de los buenos propositos, y con el compas de las consideracion, el cartabon de la rectitud, y la esquadra de la conformidad a la ley divina procure que quadre, y venga al justo a plomo, a compass, y medida todo lo que hiziere, con lo que Dios le manda.

'Sabida la ley, procure lo segundo, poner mas pura, mas limpia, y mas ygual el alma para recibir la charidad, y para esto tome la sierra de la palabra de Dios, oyendo a menudo sermons, "para que divida, y aparte" (como da a entender S. Pablo) todo lo "que fuere carne, de lo que es spiritu" [Galatians 5:17 and Hebrew 4:12]: desbaste con la azuela del arrepentimento, y acepille con el cepillo de la mortificacion su espiritu, alisandole lo mas que pudiere con la lima del recato, para que desta suerte limpia de peccados, llana sin los altos de sobervia, y baxos de la pusilanimidad, y lisa de las desordenadas passiones, sin impedimento alguno que de su alma labrada para el verdadero amor de Dios.

'Despues de limpia la consciencia, conviene lo tercero, adornarla de labores con el exercicio de las virtudes. Assiente su coraçon sobre el banco de la rectitud, y justicia, que este muy fixo con el barleto de la verdad, y con la juntera de la prudencia, escofina de la templança, y grafil de la fortaleza, vayasse labrando, y puliendo con la gubia del rendimiento, y todos los demas hierros de hazer cornijas, que son las particulares virtudes, que por ser muchas no las particularizo'. 
workshop and of the heart - beautifully correlates to the calibration of the Vita S. Joseph and the Cor Iesu amanti sacrum in Marinus van Heule's prayerbook. As Gracián juxtaposes carpentry and self-construction, the semipublic space of the workshop and the recondite chamber of the heart, so Van Heule characterises Joseph as a carpenter whose tools and materials encompass both the body and the soul, and whose heart gives evidence of the high artifice of that greatest of spiritual carpenters - Jesus.

The material spaces depicted throughout the interwoven series by Galle and Wierix are varied and complex, ranging from outdoor to indoor scenes, from oratory to temple, from bedchamber to workshop. The placement of the Cor Iesu amanti sacrum amongst two sets of scenes from Galle's Vita S. Ioseph serves to identify Wierix's intensely private cordiform images with Joseph: they become images of his heart. Conversely, they invite the votary - namely, Van Heule - to view every aspect of Joseph's vita through the filter of his heart's relation to the heart of Jesus. This is to say that the prayerbook distinguishes privacy both by kind and degree: for example, it discriminates between the public sphere of the hospitium (inn) (plate 8) [Fig. 15.2] and the private, familial sphere of the commoratio (dwelling) (plate 38). But it also distinguishes between material and spiritual privacy, between Joseph's terrestrial workshophome (plate 46) [Fig. 15.24] and the spiritual workshop into which Christ the painter transforms his adoptive father's heart (plate 26) [Fig. 15.11]. Seen in this light, the workshop as a material space redounds upon the workshop of the heart, and vice-versa, so that one kind of privacy comes to signify, by a process of analogy, the other kind. Or put differently, the material circumstances of Joseph's life can be seen to allude to that life's spiritual circumstances, almost to function as an allegory of them, and complementarily, to be converted into an allegory by them. 


\section{Detrausue met de $f f$ maghet}

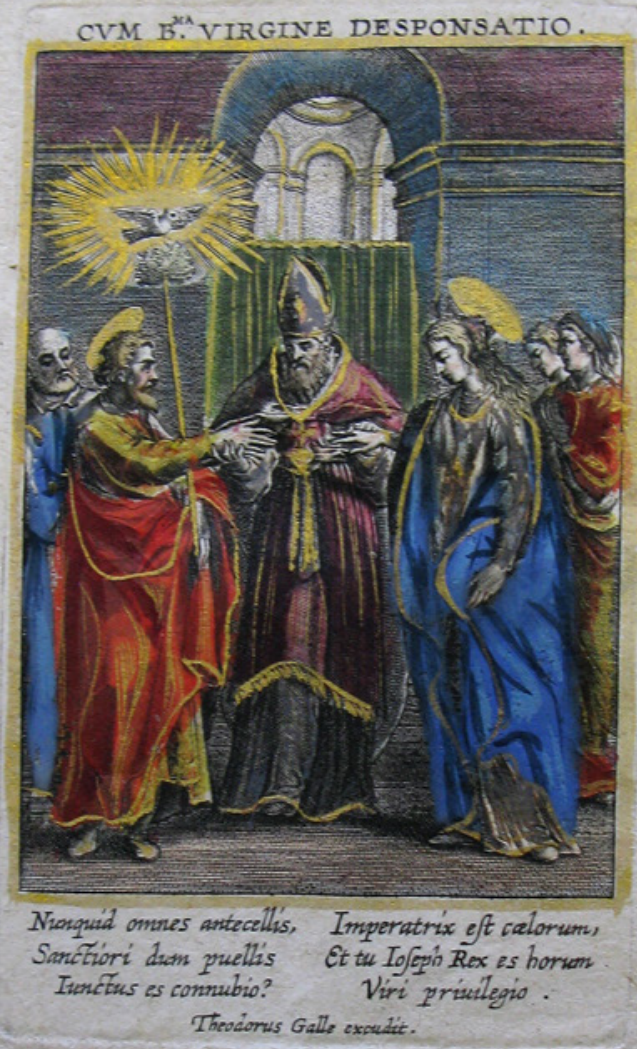

Traut ghi des hemels Coninghin Soo moet ghijharen Coninck siyn: Want, het terfdeel dat de uraw aengact Doorhourolix recht den man toestact.

FIGURE 15.1 Theodoor, Cornelis, and/or Jan Galle, "Cum beatissima Virgine desponsatio" (Betrothal to the Most Blessed Virgin), from Vita S. Joseph beatissimae Virginis sponsi patriarcharum maximi iconibus delineata ac versiculis ornata (Life of St.Joseph, Husband of the Most Blessed Virgin, Greatest of the Patriarchs, Portrayed in Images and Ornamented with Verses), ca. 16o1-1633. Engraving, $8.7 \times 6.3 \mathrm{~cm}$. Antwerp, Plantin Moretus Museum, MPM R 35 


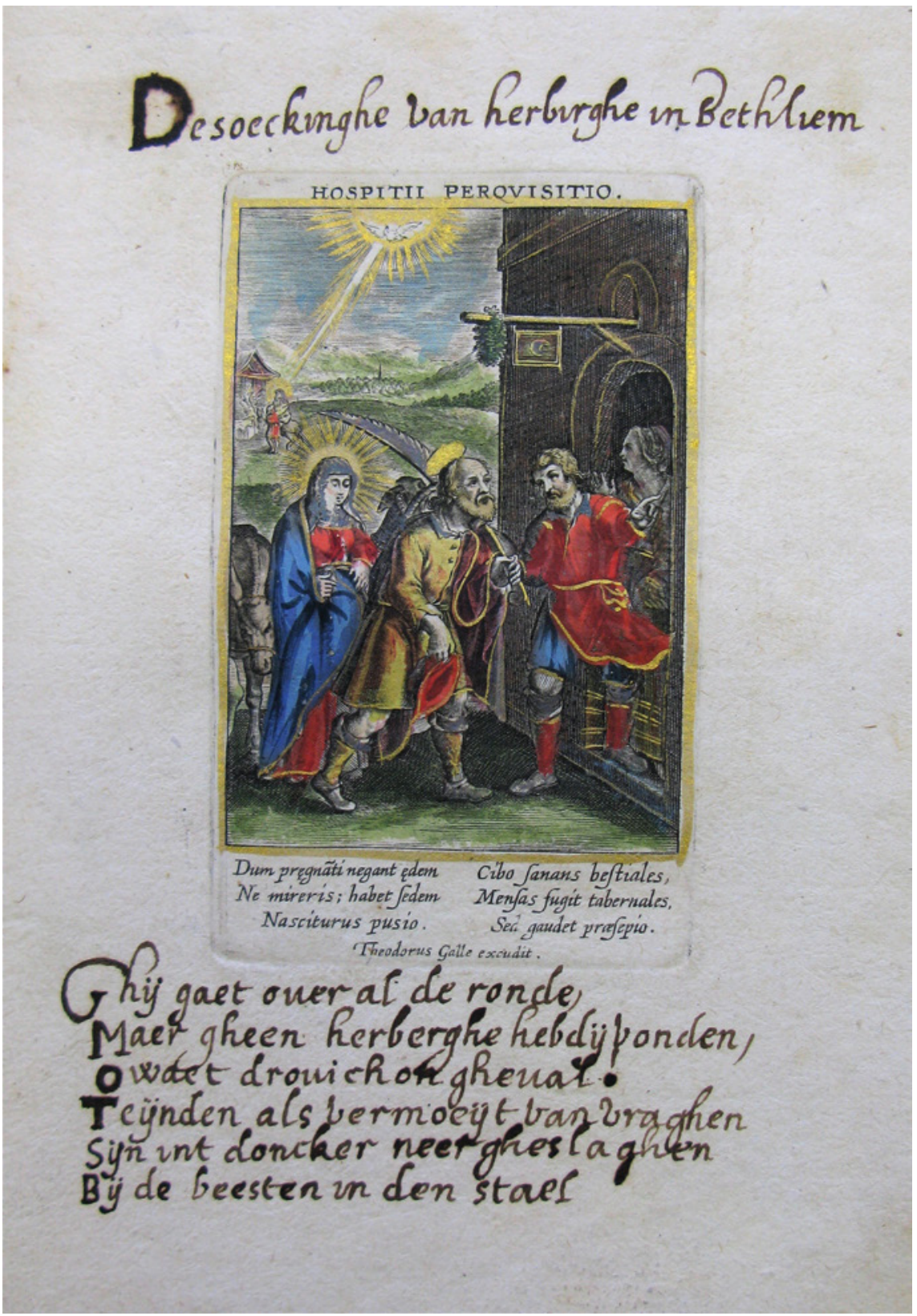

FIGURE 15.2 Theodoor, Cornelis, and/or Jan Galle, "Hospitii perquisitio" (Search for Lodging), from Vita S. Joseph beatissimae Virginis sponsi patriarcharum maximi iconibus delineata ac versiculis ornata (Life of St.Joseph, Husband of the Most Blessed Virgin, Greatest of the Patriarchs, Portrayed in Images and Ornamented with Verses), ca. 16o1-1633. Engraving, $8.8 \times 5.3 \mathrm{~cm}$. Antwerp, Plantin Moretus Museum, MPM R 35 


\section{Debaringhe ban de maechdelicke brüt}

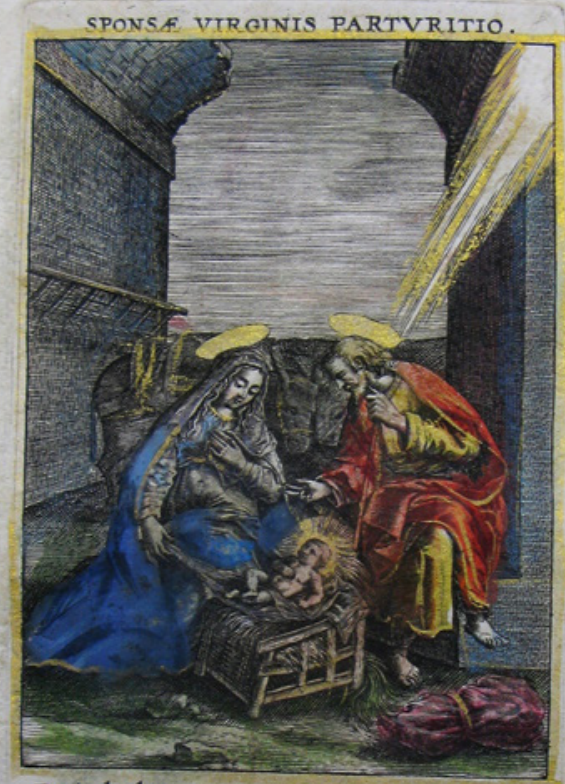

Patriercha laus eft magni, Clare vides huene nafentem, It videret diem Agni. Prinus audis vagientem, Vidit, fed in peculo. Adoras in fabulo.

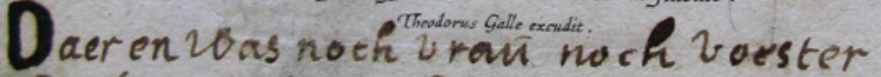
Die daer dede enich coster Aaen het kmt oft aen de mareht Dact ghij iofeshidue clen boeder syt lan bey de knt en moeder Dic als vadersorghe dracht

FIGURE 15.3 Theodoor, Cornelis, and/or Jan Galle, "Sponsae Virginis parturitio"

(Parturition of the Virgin Bride), from Vita S. Joseph beatissimae Virginis sponsi patriarcharum maximi iconibus delineata ac versiculis ornata (Life of St. Joseph, Husband of the Most Blessed Virgin, Greatest of the Patriarchs, Portrayed in Images and Ornamented with Verses), ca. 16o1-1633. Engraving, 8.9 × 5.3 cm. Antwerp, Plantin Moretus Museum, MPM R 35 


\section{De blucht naer Azgipten}

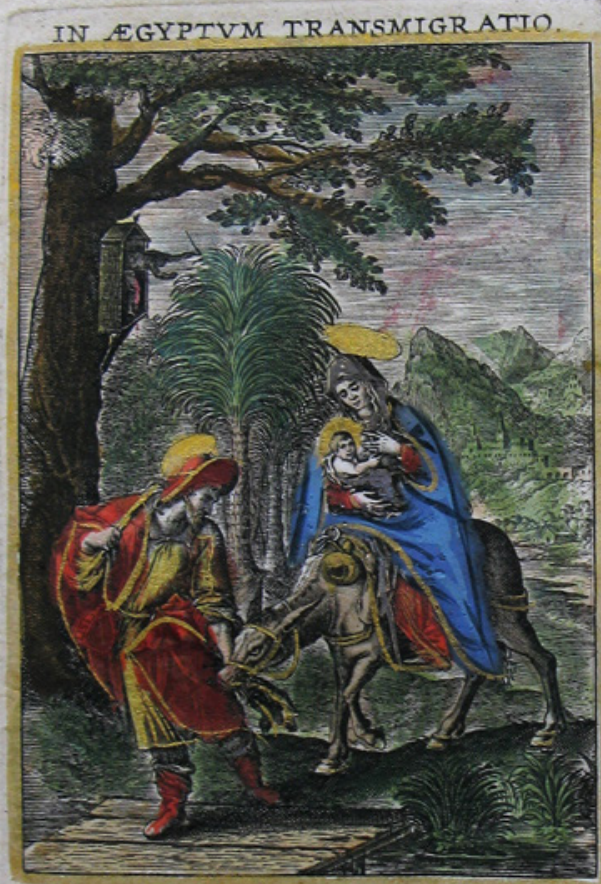

Gentricem cum puello Iter forsan aberraret, Ducit Ioseph in asello, Secum viam ciom portaret His habens fe prequium. Et Solem perlucidum?

A aensut toch wseph $g$ iny heÿle ghen man in waet enenfighy ini gheselt syt en ircest nocfinict ten, 25 ghen tÿt leant ghy hete het hut des ionlers in is bo odenis

FIGURE 15.4 Theodoor, Cornelis, and/or Jan Galle, "In Aegyptum transmigratio" (Flight into Egypt), from Vita S. Joseph beatissimae Virginis sponsi patriarcharum maximi iconibus delineata ac versiculis ornata (Life of St. Joseph, Husband of the Most Blessed Virgin, Greatest of the Patriarchs, Portrayed in Images and Ornamented with Verses), ca. 16o1-1633. Engraving, 8.9 ×5.3 cm. Antwerp, Plantin Moretus Museum, MPM R 35 


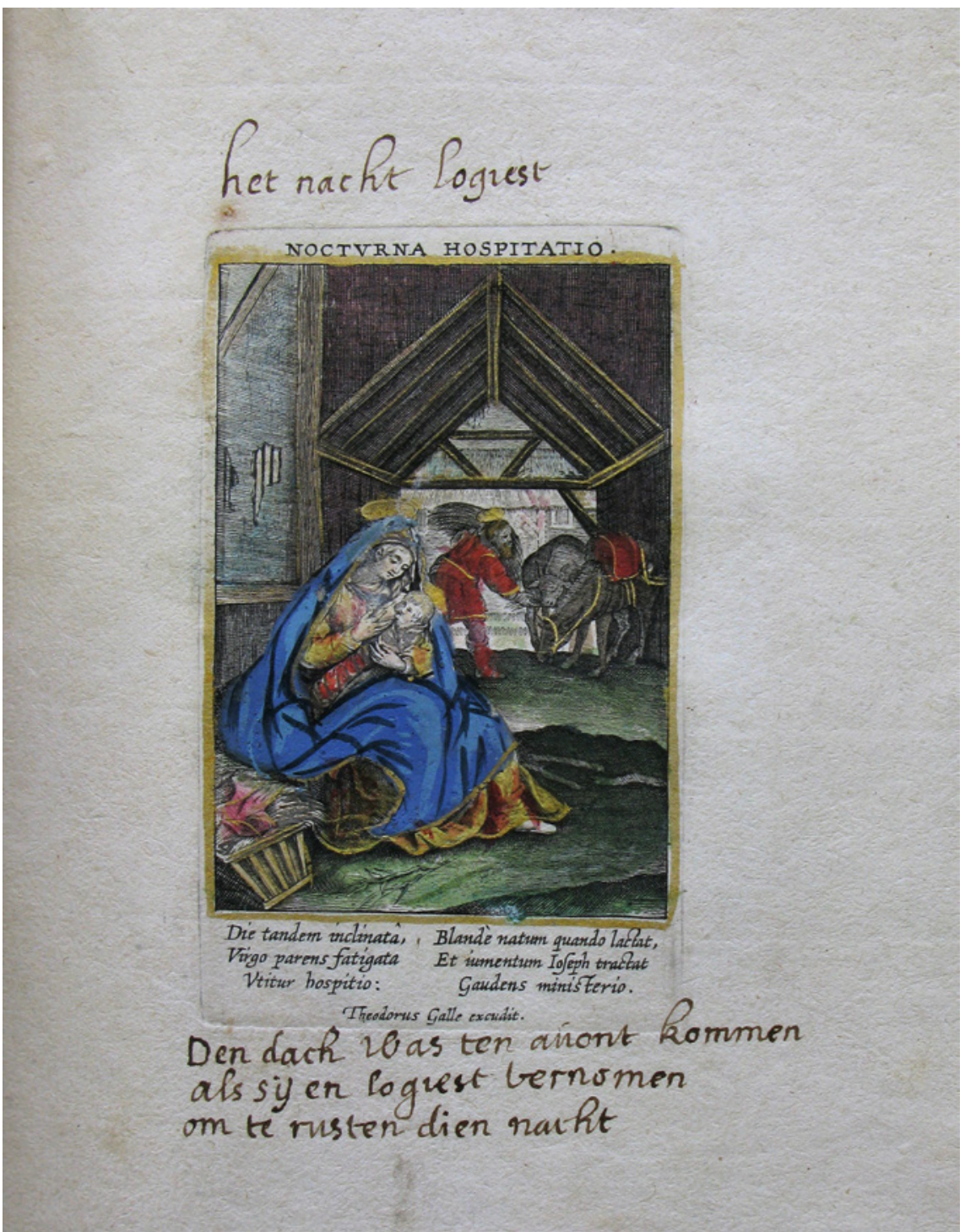

FIGURE 15.5 Theodoor, Cornelis, and/or Jan Galle, Theodoor, Cornelis, and/or Jan Galle, "Nocturna hospitatio" (Nocturnal Lodging), from Vita S. Joseph beatissimae Virginis sponsi patriarcharum maximi iconibus delineata ac versiculis ornata (Life of St. Joseph, Husband of the Most Blessed Virgin, Greatest of the Patriarchs, Portrayed in Images and Ornamented with Verses), ca. 1601-1633. Engraving, $8.8 \times 5.4 \mathrm{~cm}$. Antwerp, Plantin Moretus Museum, MPM R 35 


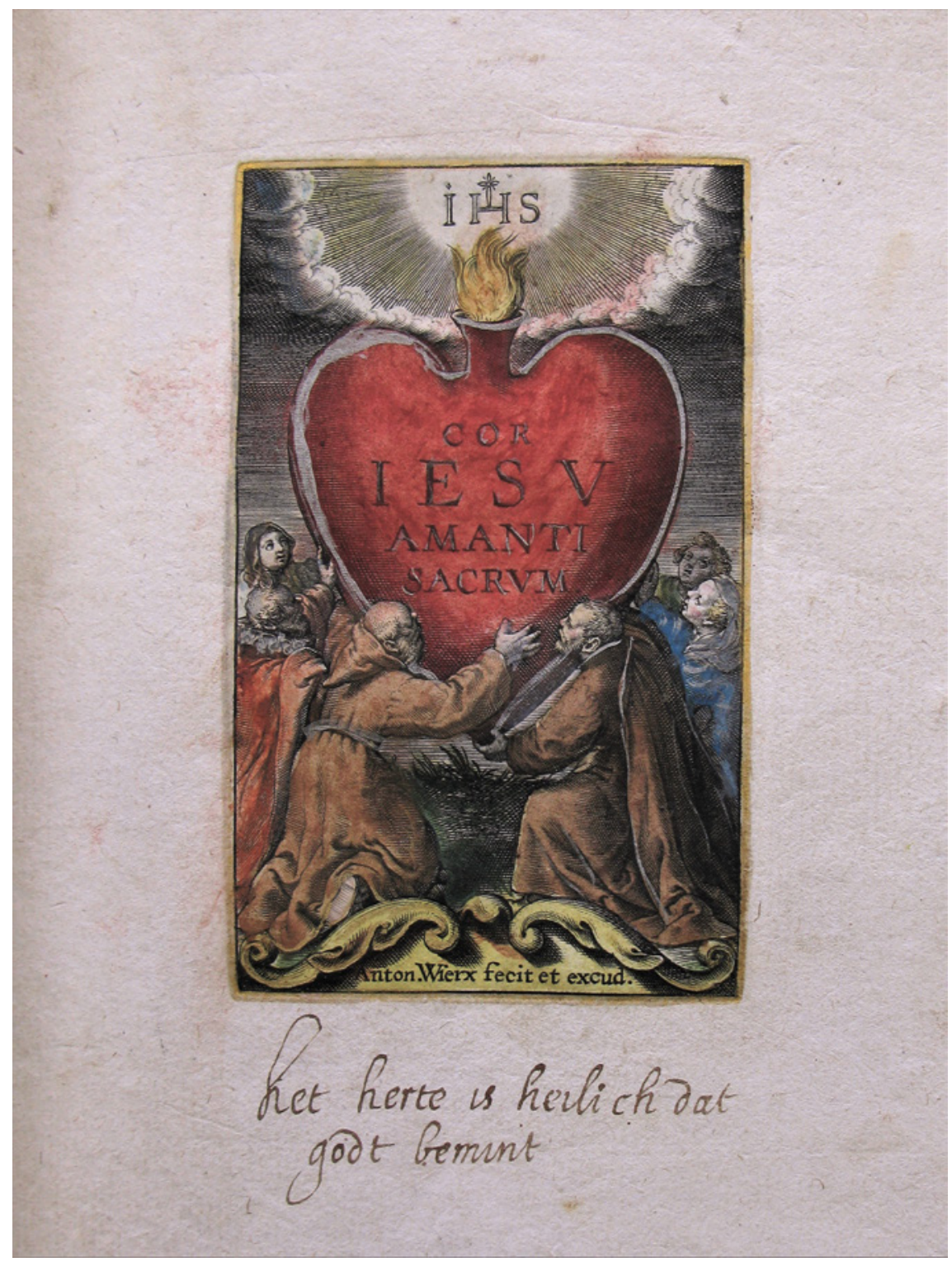

FIGURE 15.6 Antoon II Wierix, Cor Iesu amanti sacrum (Heart of Jesus Sacred to the Loving Votary or, alternatively, Heart Sacred to the Loving Votary of Jesus) (Antwerp, Antoon II Wierix: before 16o4), title-page. Engraving, $9.1 \times 5.6 \mathrm{~cm}$. Antwerp, Plantin Moretus Museum, MPM R 35 


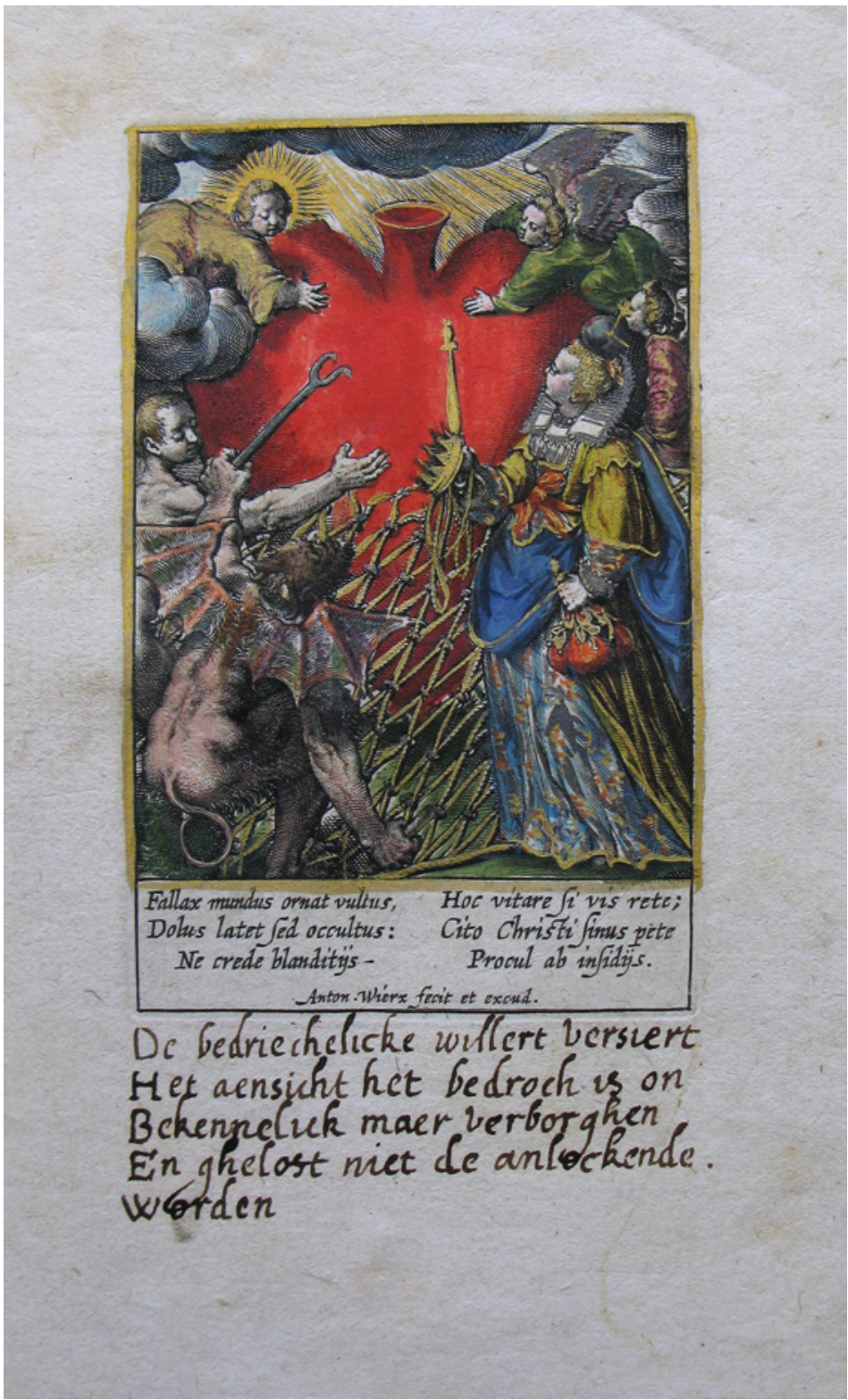

FIGURE 15.7 Antoon II Wierix, "Fallax mundus ornat vultus" (The false world adorns her face), from Cor Iesu amanti sacrum (Heart of Jesus Sacred to the Loving Votary or, alternatively, Heart Sacred to the Loving Votary of Jesus), in Vita S. Ioseph beatissimae Virg inis sponsi patriarcharum maximi iconibus delineata ac versiculis ornata (Life of St. Joseph, Husband of the Most Blessed Virgin, Greatest of the Patriarchs, Portrayed in Images and Ornamented with Verses), ca. 1601-1633. Engraving, $9.1 \times 5.7 \mathrm{~cm}$. Antwerp, Plantin Moretus Museum, MPM R 35 


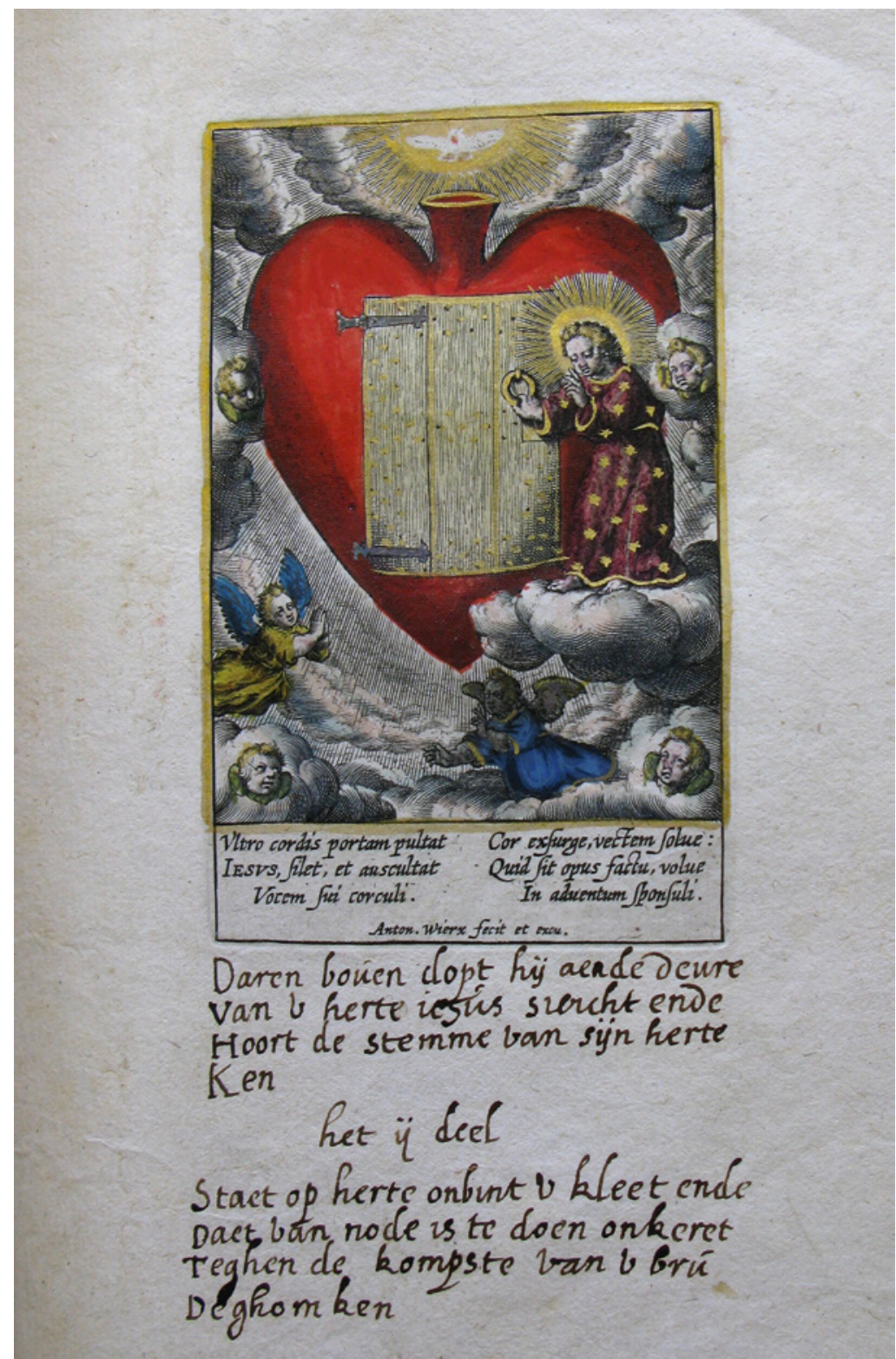

FIGURE 15.8 Antoon II Wierix, "Ultro cordis portam pultat" ([Christ] knocks at the door of the [shuttered] heart), from Cor Iesu amanti sacrum (Heart of Jesus Sacred to the Loving Votary or, alternatively, Heart Sacred to the Loving Votary of Jesus), in Vita S. Ioseph beatissimae Virginis sponsi patriarcharum maximi iconibus delineata ac versiculis ornata (Life of St. Joseph, Husband of the Most Blessed Virgin, Greatest of the Patriarchs, Portrayed in Images and Ornamented with Verses), ca. 16o1-1633. Engraving, $9.1 \times 5.7$ cm. Antwerp, Plantin Moretus Museum, MPM R 35 


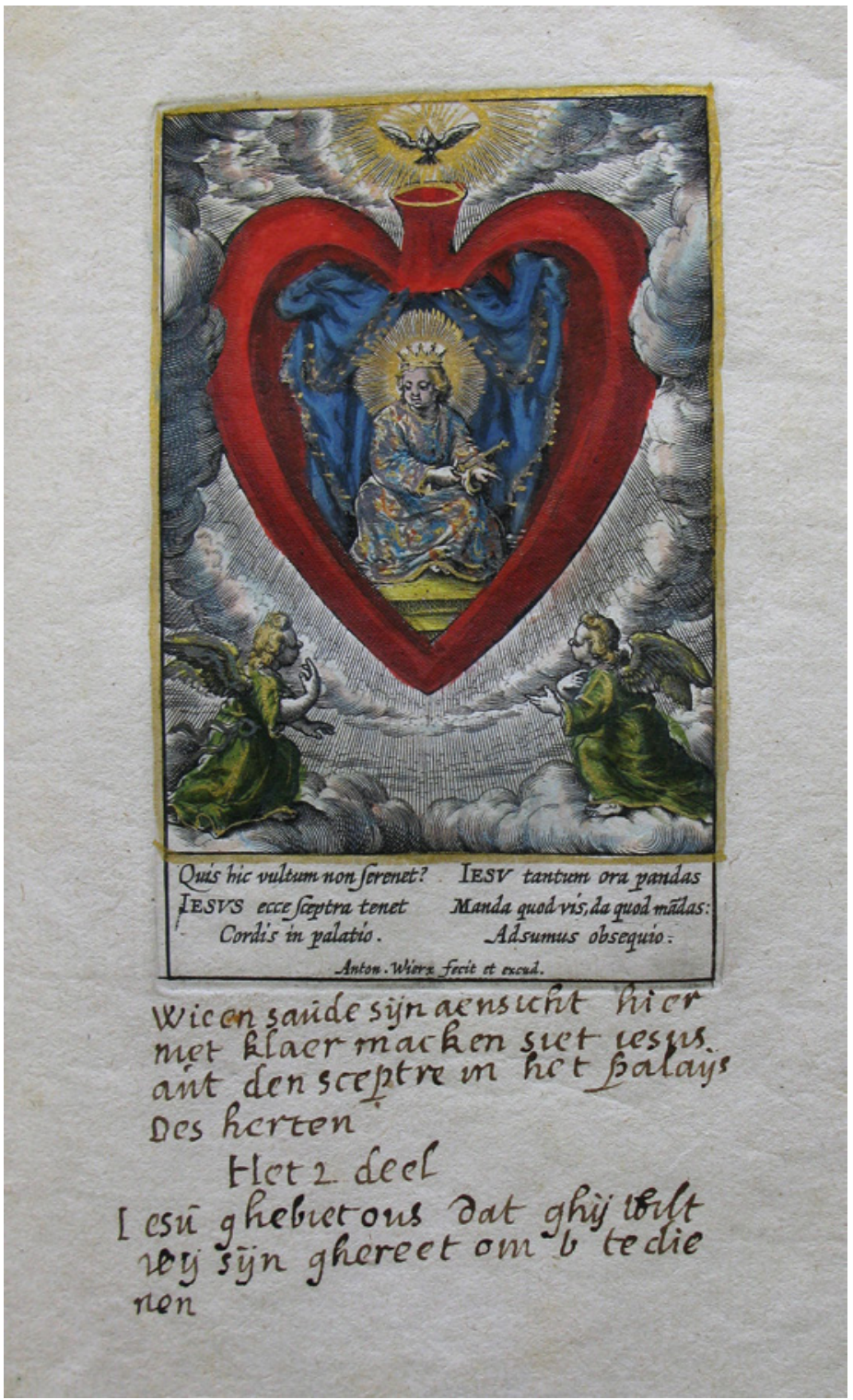

FIGURE 15.9 Antoon II Wierix, "Quis hic vultum non serenet?" (Whose face does he not make serene?), from Cor Iesu amanti sacrum (Heart of Jesus Sacred to the Loving Votary or, alternatively, Heart Sacred to the Loving Votary of Jesus), in Vita S. Ioseph beatissimae Virginis sponsi patriarcharum maximi iconibus delineata ac versiculis ornata (Life of St.Joseph, Husband of the Most Blessed Virgin, Greatest of the Patriarchs, Portrayed in Images and Ornamented with Verses), ca. 16o1-1633. Engraving, $9.2 \times 5.6 \mathrm{~cm}$. Antwerp, Plantin Moretus Museum, MPM R 35 


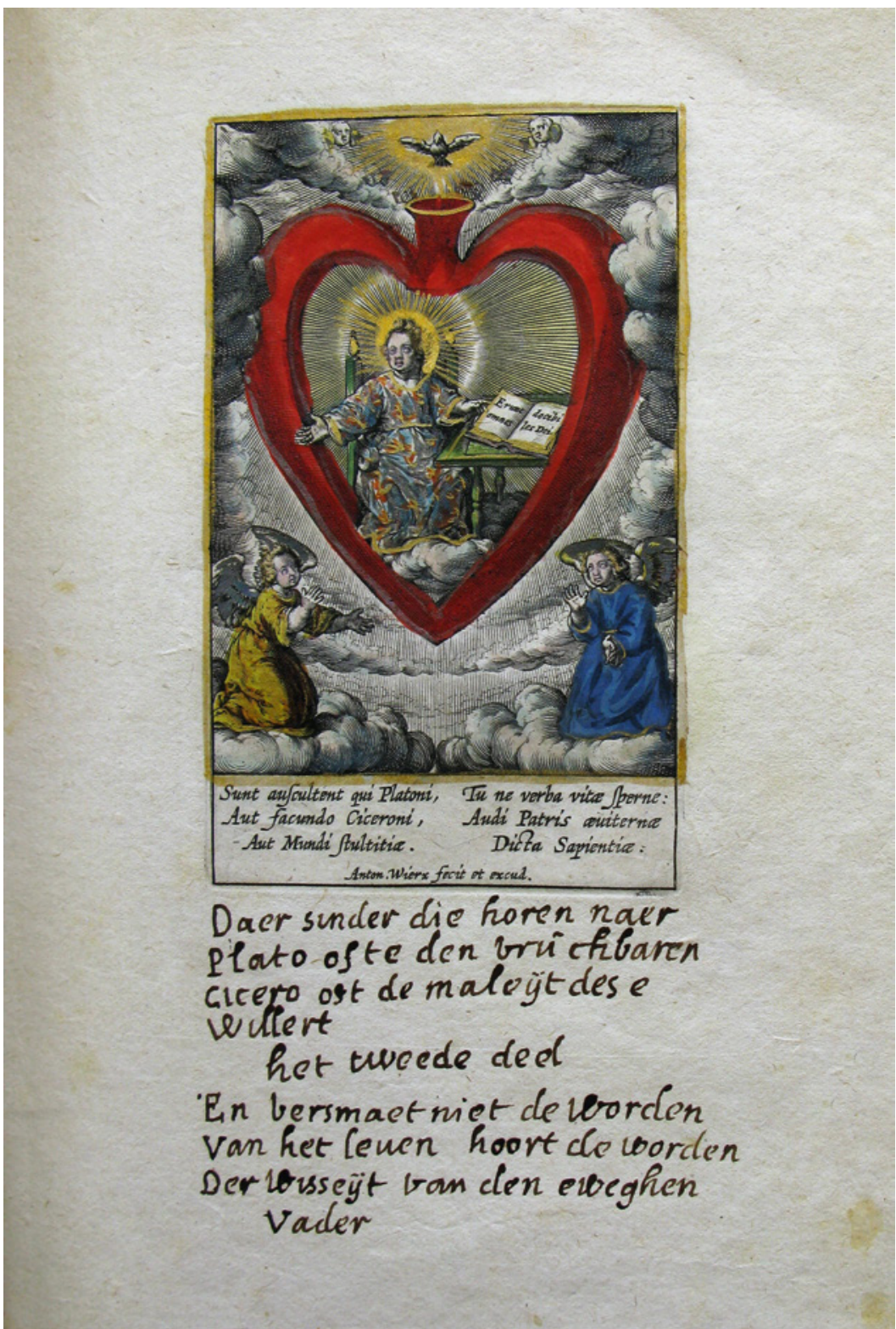

FIGURE 15.10 Antoon II Wierix, "Sunt auscultent qui Platoni" (These are they who give ear to Plato), from Cor Iesu amanti sacrum (Heart of Jesus Sacred to the Loving Votary or, alternatively, Heart Sacred to the Loving Votary of Jesus), in Vita S. Ioseph beatissimae Virginis sponsi patriarcharum maximi iconibus delineata ac versiculis ornata (Life of St.Joseph, Husband of the Most Blessed Virgin, Greatest of the Patriarchs, Portrayed in Images and Ornamented with Verses), ca. 1601-1633. Engraving, $9.1 \times 5.4 \mathrm{~cm}$. Antwerp, Plantin Moretus Museum, MPM R 35 


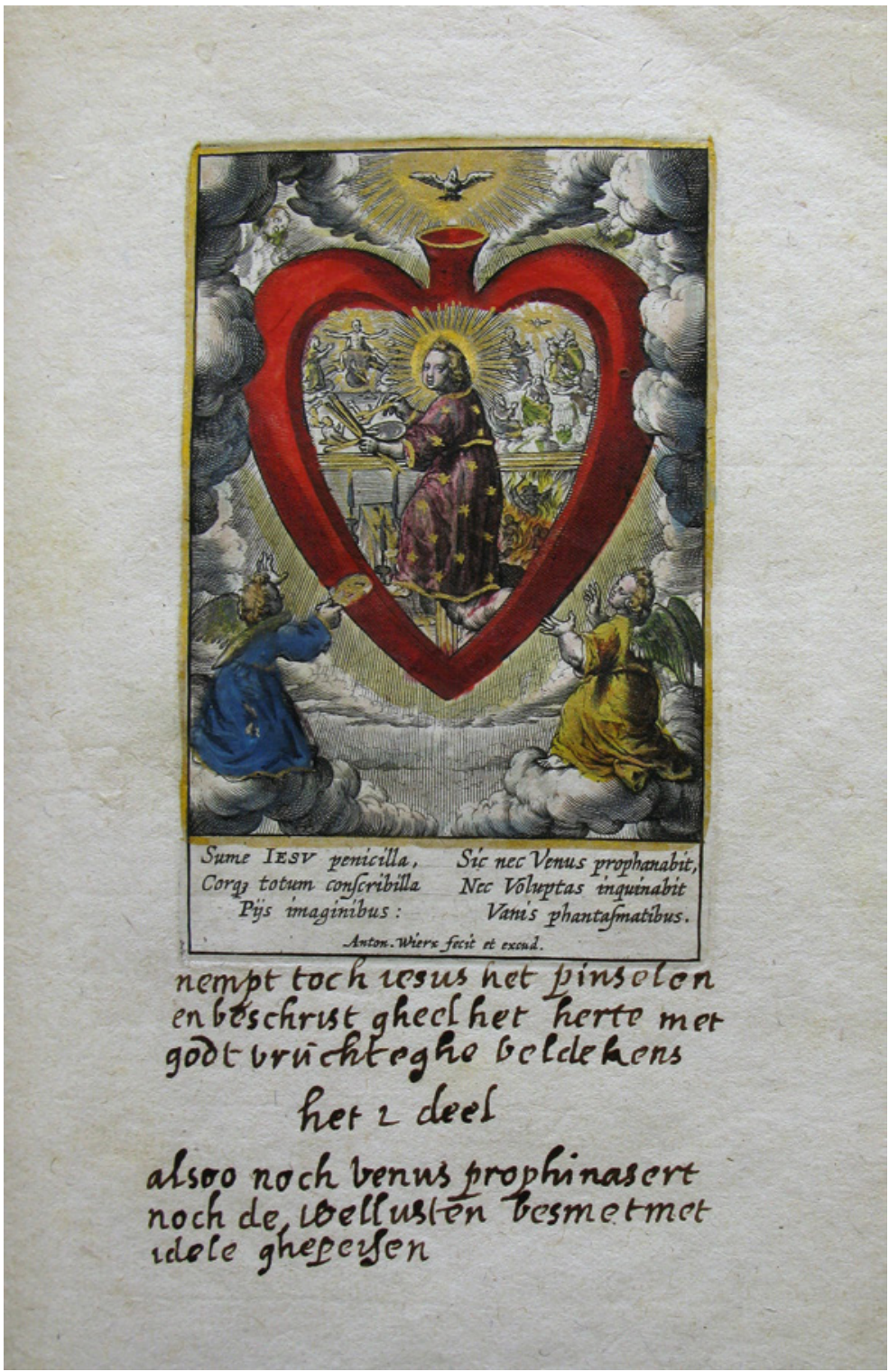

FIGURE 15.11 Antoon II Wierix, "Sume Iesu penicilla" (Jesus, grab hold of the little brushes), from Cor Iesu amanti sacrum (Heart of Jesus Sacred to the Loving Votary or, alternatively, Heart Sacred to the Loving Votary of Jesus), in Vita S. Ioseph beatissimae Virginis sponsi patriarcharum maximi iconibus delineata ac versiculis ornata (Life of St. Joseph, Husband of the Most Blessed Virgin, Greatest of the Patriarchs, Portrayed in Images and Ornamented with Verses), ca. 16o1-1633. Engraving, 9.1 ×5.7 cm. Antwerp, Plantin Moretus Museum, MPM R 35 


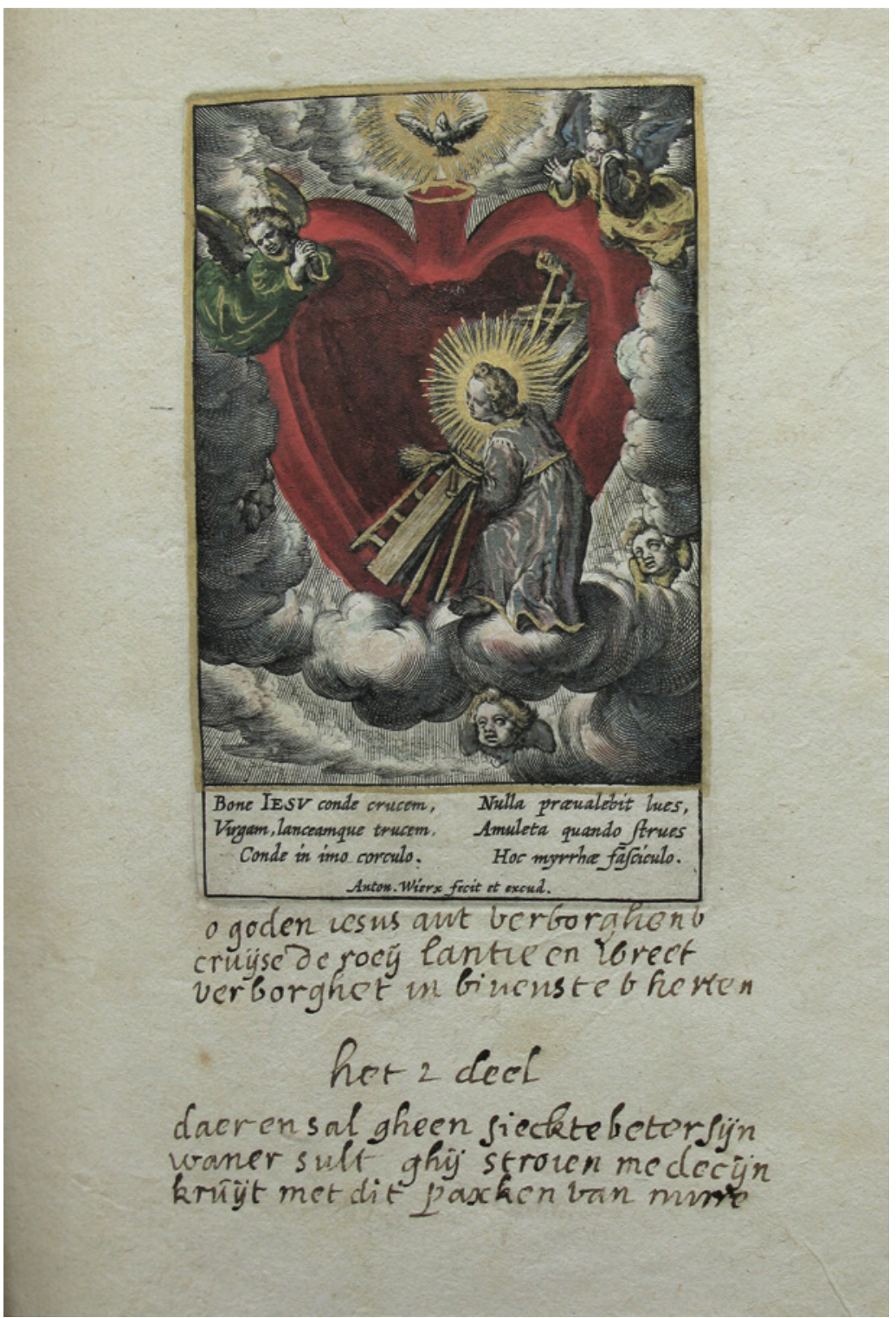

FIGURE 15.12 Antoon II Wierix, "Bone Iesu conde crucem" (Good Jesus, fashion the cross), from Cor Iesu amanti sacrum (Heart of Jesus Sacred to the Loving Votary or, alternatively, Heart Sacred to the Loving Votary of Jesus), in Vita S. Ioseph beatissimae Virginis sponsi patriarcharum maximi iconibus delineata ac versiculis ornata (Life of St.Joseph, Husband of the Most Blessed Virgin, Greatest of the Patriarchs, Portrayed in Images and Ornamented with Verses), ca. 1601-1633. Engraving, $9.0 \times 5.6 \mathrm{~cm}$. Antwerp, Plantin Moretus Museum, MPM R 35 


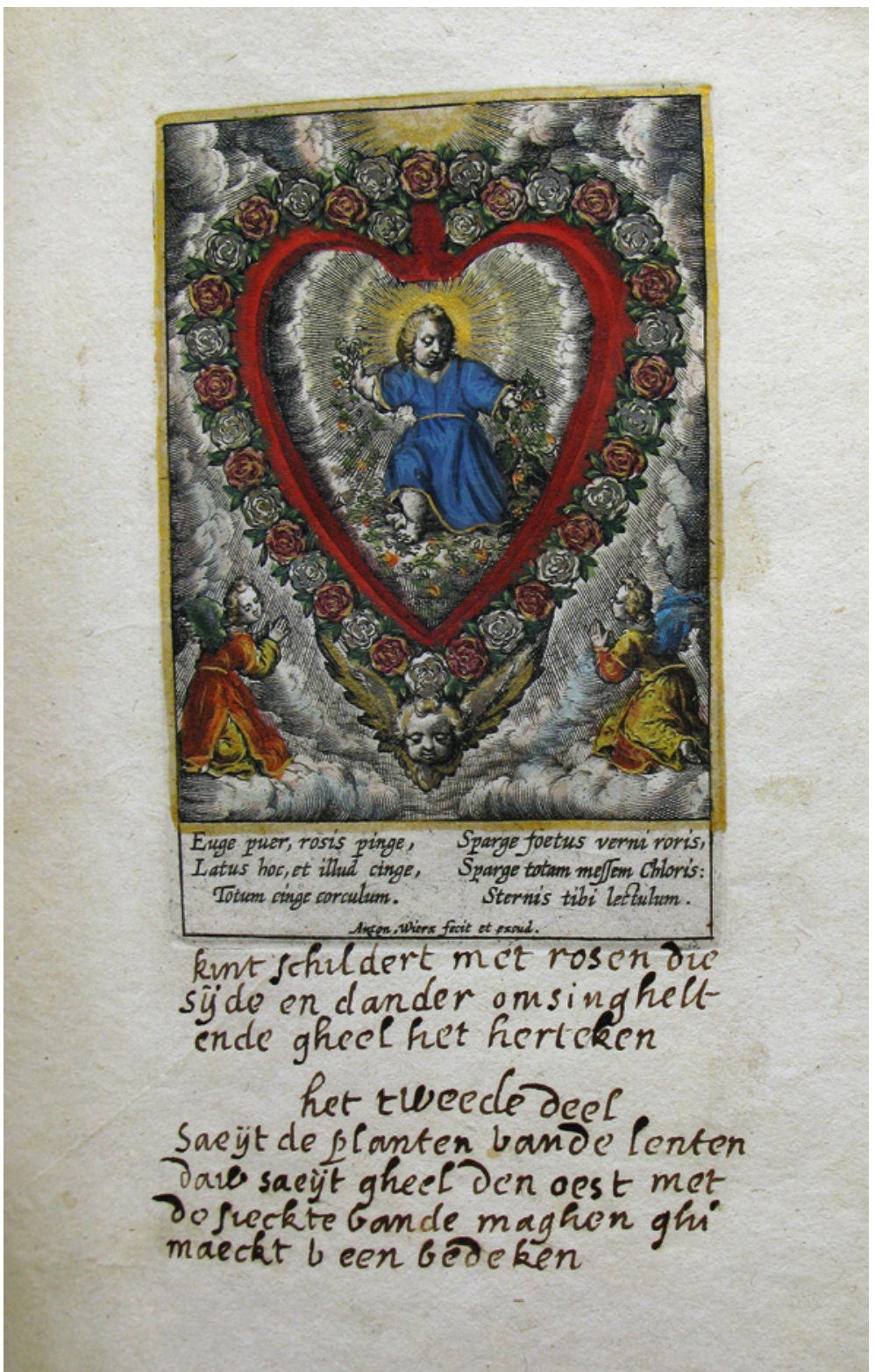

FIGURE 15.13 Antoon II Wierix, "Euge puer, rosis pinge" (Bravo, boy, embroider with roses), from Cor Iesu amanti sacrum (Heart of Jesus Sacred to the Loving Votary or, alternatively, Heart Sacred to the Loving Votary of Jesus), in Vita S. Ioseph beatissimae Virginis sponsi patriarcharum maximi iconibus delineata ac versiculis ornata (Life of St. Joseph, Husband of the Most Blessed Virgin, Greatest of the Patriarchs, Portrayed in Images and Ornamented with Verses), ca. 16o1-1633. Engraving, $9.0 \times 5.8 \mathrm{~cm}$. Antwerp, Plantin Moretus Museum, MPM R 35 


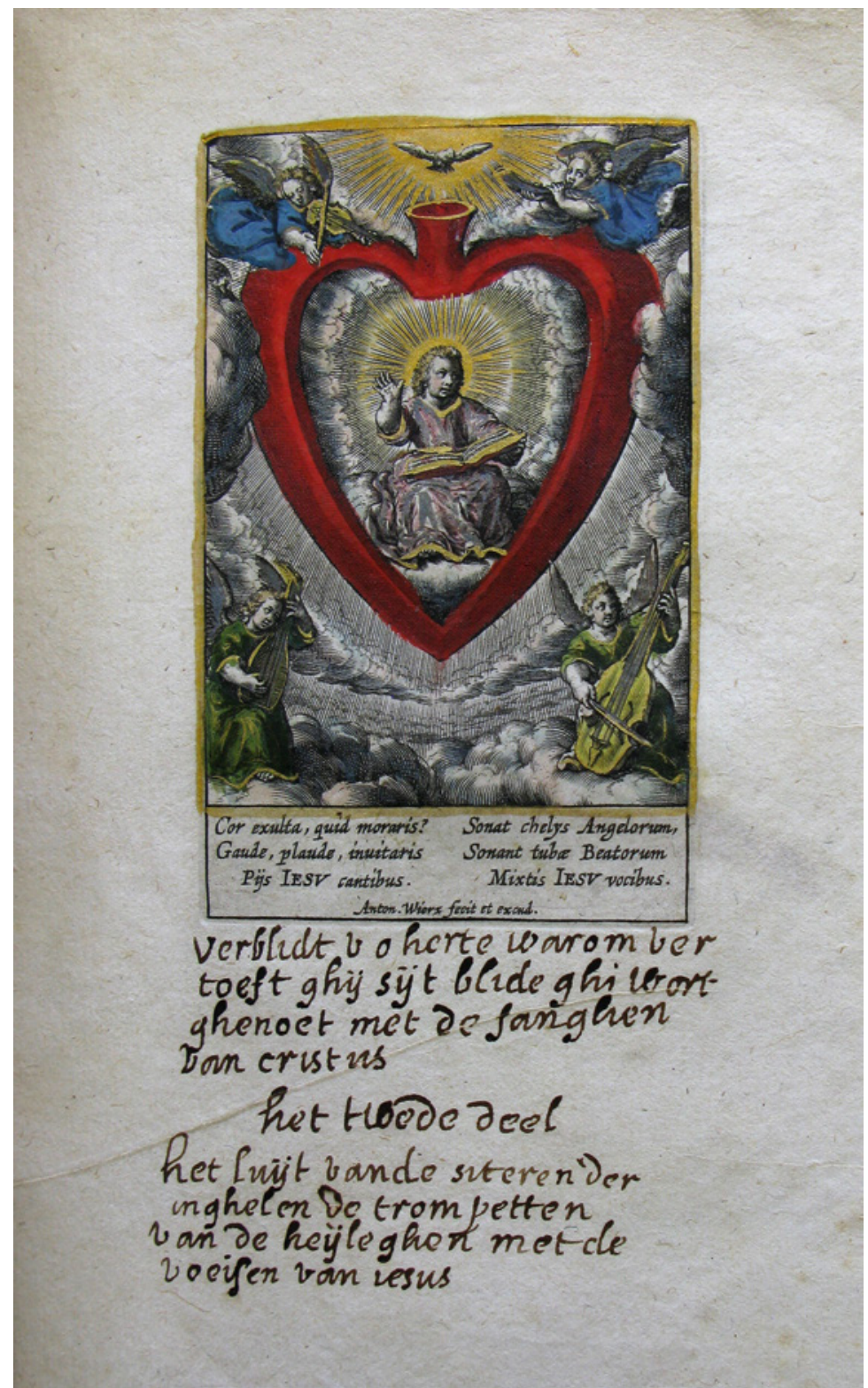

FIGURE 15.14 Antoon II Wierix, “Cor exulta, quid moraris?” (Rejoice, heart, why do you delay?), from Cor Iesu amanti sacrum (Heart of Jesus Sacred to the Loving Votary or, alternatively, Heart Sacred to the Loving Votary of Jesus), in Vita S. Ioseph beatissimae Virginis sponsi patriarcharum maximi iconibus delineata ac versiculis ornata (Life of St. Joseph, Husband of the Most Blessed Virgin, Greatest of the Patriarchs, Portrayed in Images and Ornamented with Verses), ca. 16o1-1633. Engraving, $9.1 \times 5.6 \mathrm{~cm}$. Antwerp, Plantin Moretus Museum, MPM R 35 


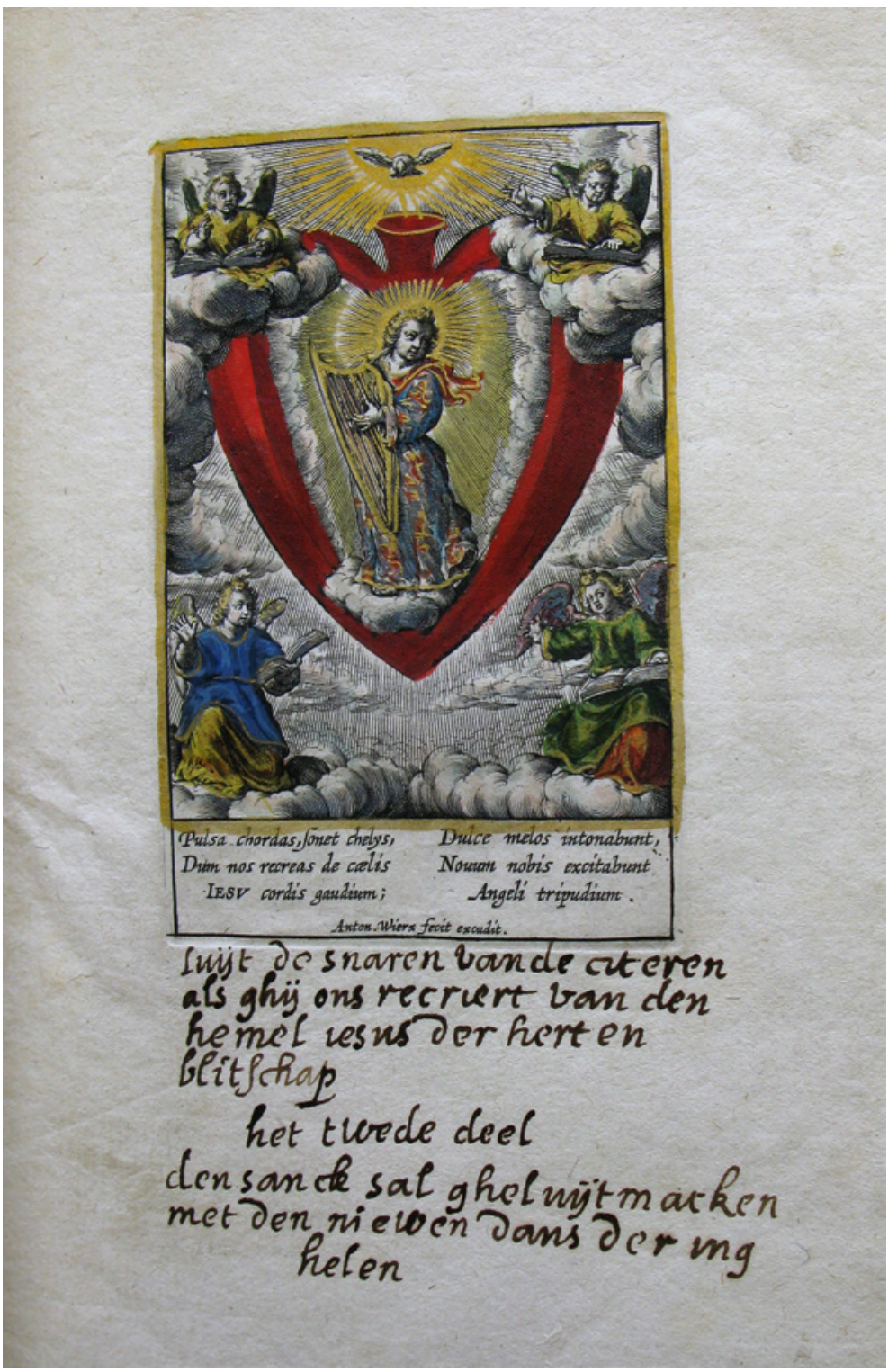

FIGURE 15.15 Antoon II Wierix, "Pulsa chordas, sonet chelys" (Pluck the strings, let the lyre sound), from Cor Iesu amanti sacrum (Heart of Jesus Sacred to the Loving Votary or, alternatively, Heart Sacred to the Loving Votary of Jesus), in Vita S. Ioseph beatissimae Virginis sponsi patriarcharum maximi iconibus delineata ac versiculis ornata (Life of St.Joseph, Husband of the Most Blessed Virgin, Greatest of the Patriarchs, Portrayed in Images and Ornamented with Verses), ca. 16o1-1633. Engraving, 9.1 ×5.8 cm. Antwerp, Plantin Moretus Museum, MPM R 35 


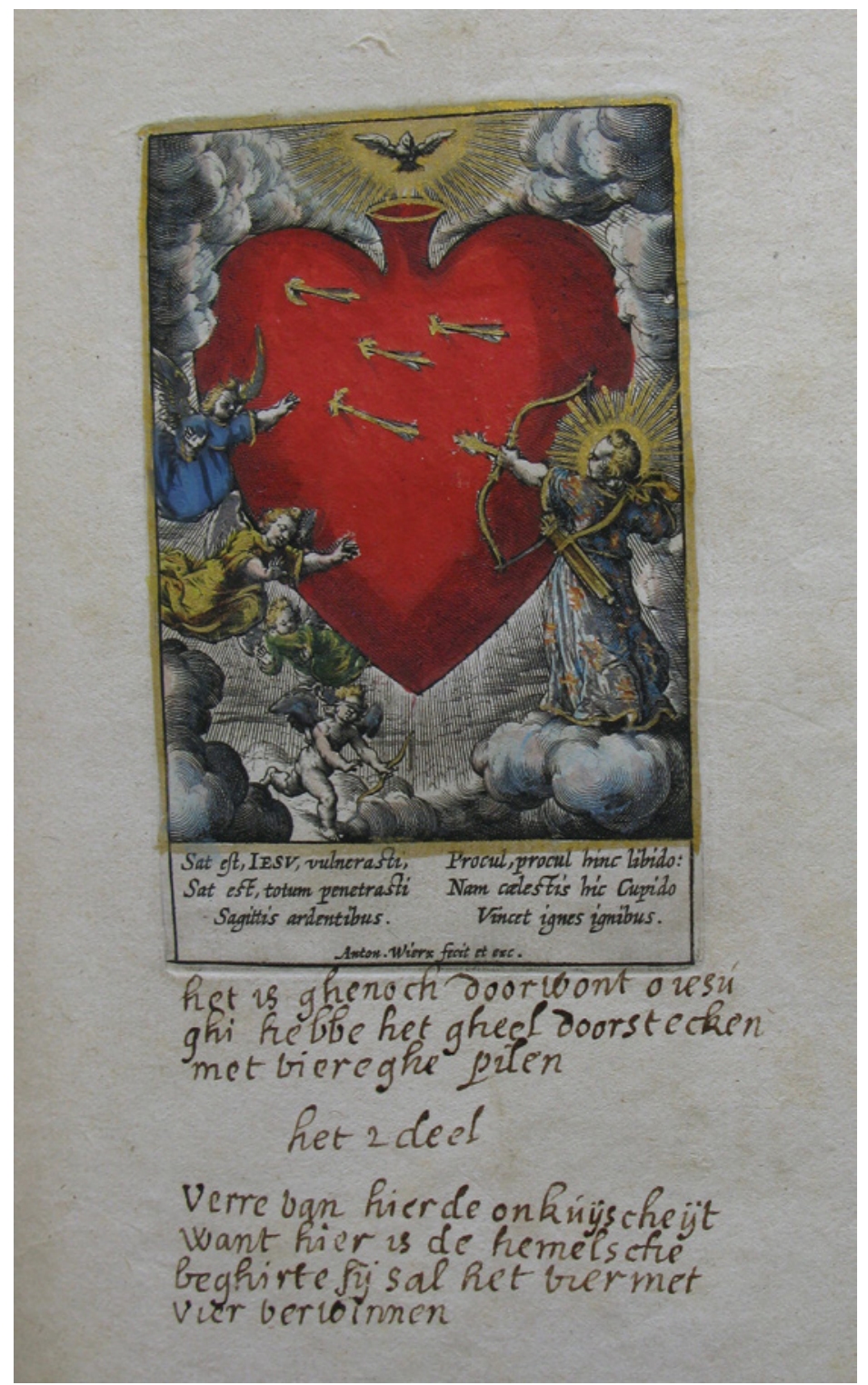

FIGURE 15.16 Antoon II Wierix, "Sat est, Iesu, vulnerasti" (Enough now, Jesus, you have wounded it), from Cor Iesu amanti sacrum (Heart of Jesus Sacred to the Loving Votary or, alternatively, Heart Sacred to the Loving Votary of Jesus), in Vita S. Ioseph beatissimae Virginis sponsi patriarcharum maximi iconibus delineata ac versiculis ornata (Life of St. Joseph, Husband of the Most Blessed Virgin, Greatest of the Patriarchs, Portrayed in Images and Ornamented with Verses), ca. 1601-1633. Engraving, $9.1 \times 5.7 \mathrm{~cm}$. Antwerp, Plantin Moretus Museum, MPM R 35 


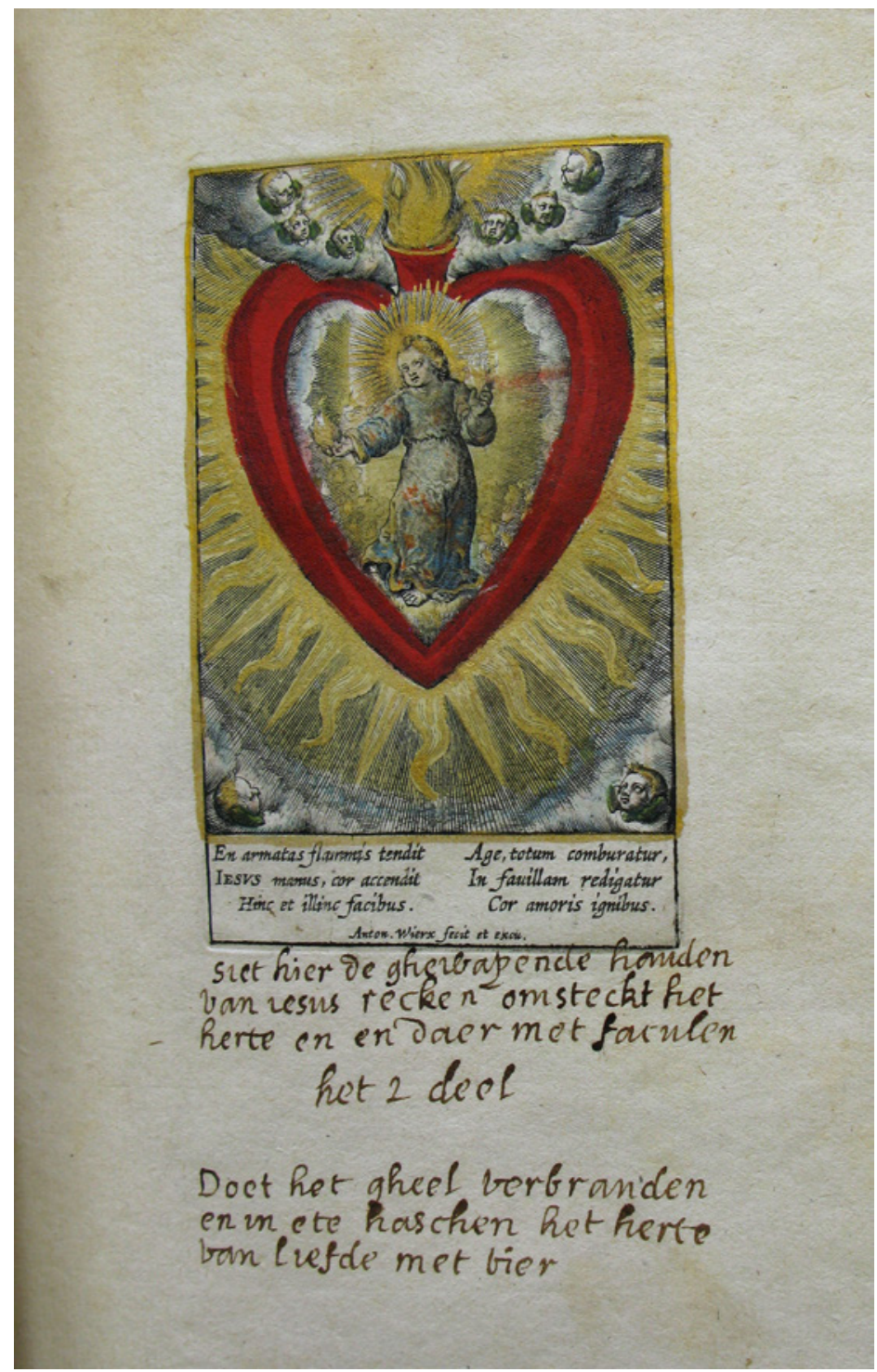

FIGURE 15.17 Antoon II Wierix, "En armatas flammis tendit Iesus manus" (Behold, Jesus extends his hands armed with flames), from Cor Iesu amanti sacrum (Heart of Jesus Sacred to the Loving Votary or, alternatively, Heart Sacred to the Loving Votary of Jesus), in Vita S. Ioseph beatissimae Virginis sponsi patriarcharum maximi iconibus delineata ac versiculis ornata (Life of St. Joseph, Husband of the Most Blessed Virgin, Greatest of the Patriarchs, Portrayed in Images and Ornamented with Verses), ca. 1601-1633. Engraving, 9.1 × 5.6 cm. Antwerp, Plantin Moretus Museum, MPM R 35 


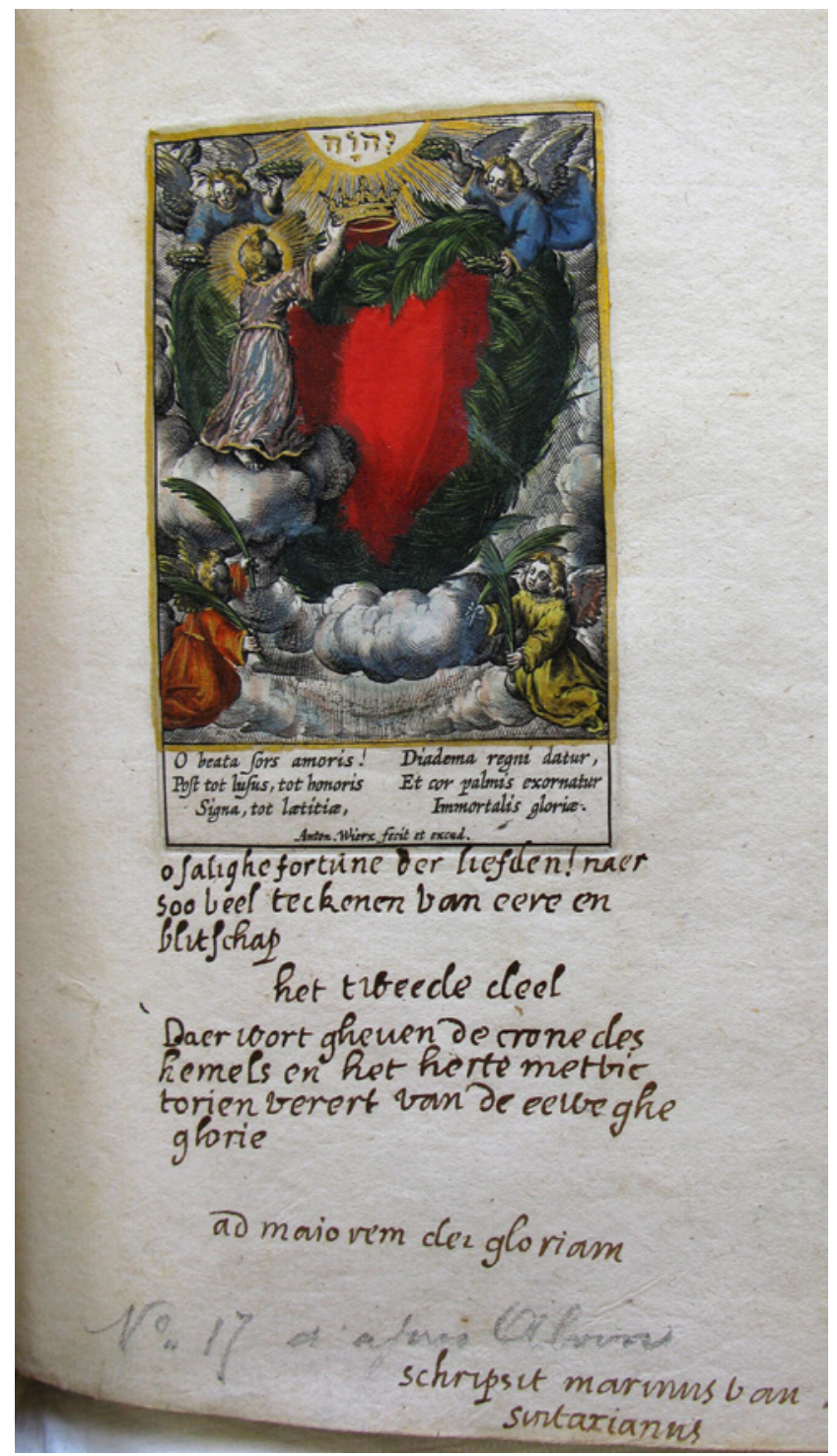

FIGURE 15.18 Antoon II Wierix, “O beata sors amoris!" (O blessed condition of love), from Cor Iesu amanti sacrum (Heart of Jesus Sacred to the Loving Votary or, alternatively, Heart Sacred to the Loving Votary of Jesus), in Vita S. Ioseph beatissimae Virginis sponsi patriarcharum maximi iconibus delineata ac versiculis ornata (Life of St. Joseph, Husband of the Most Blessed Virgin, Greatest of the Patriarchs, Portrayed in Images and Ornamented with Verses), ca. 16o1-1633. Engraving, 9.0 ×5.5 cm. Antwerp, Plantin Moretus Museum, MPM R 35 


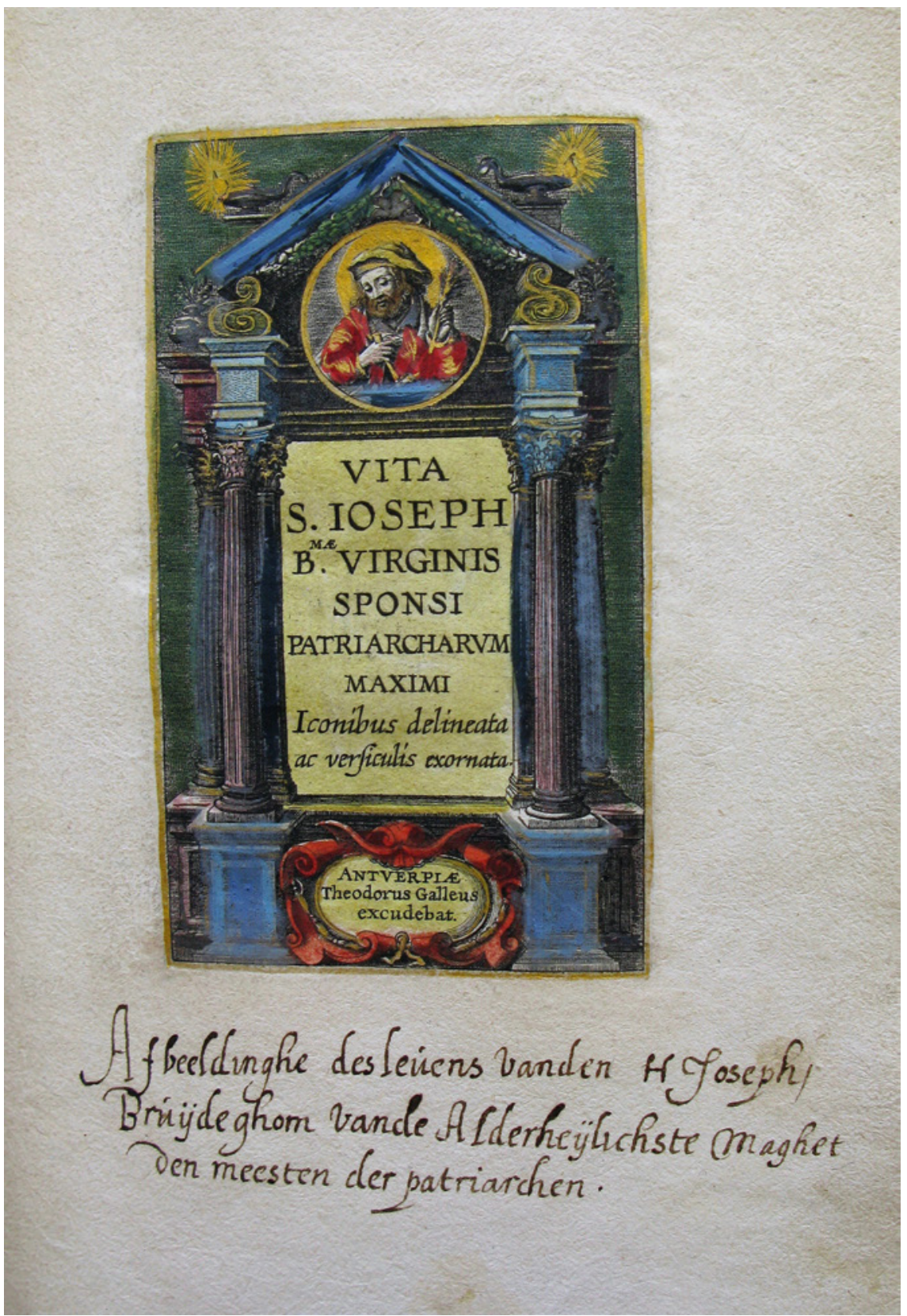

FIGURE 15.19 Theodoor Galle, Vita S.Joseph beatissimae Virginis sponsi patriarcharum maximi iconibus delineata ac versiculis ornata (Life of St. Joseph, Husband of the Most Blessed Virgin, Greatest of the Patriarchs, Portrayed in Images and Ornamented with Verses) (Antwerp, Theodoor Galle: ca. 16o1-1633). Engraving, $10.1 \times 6 \mathrm{~cm}$. Antwerp, Plantin Moretus Museum, M PM R 35 


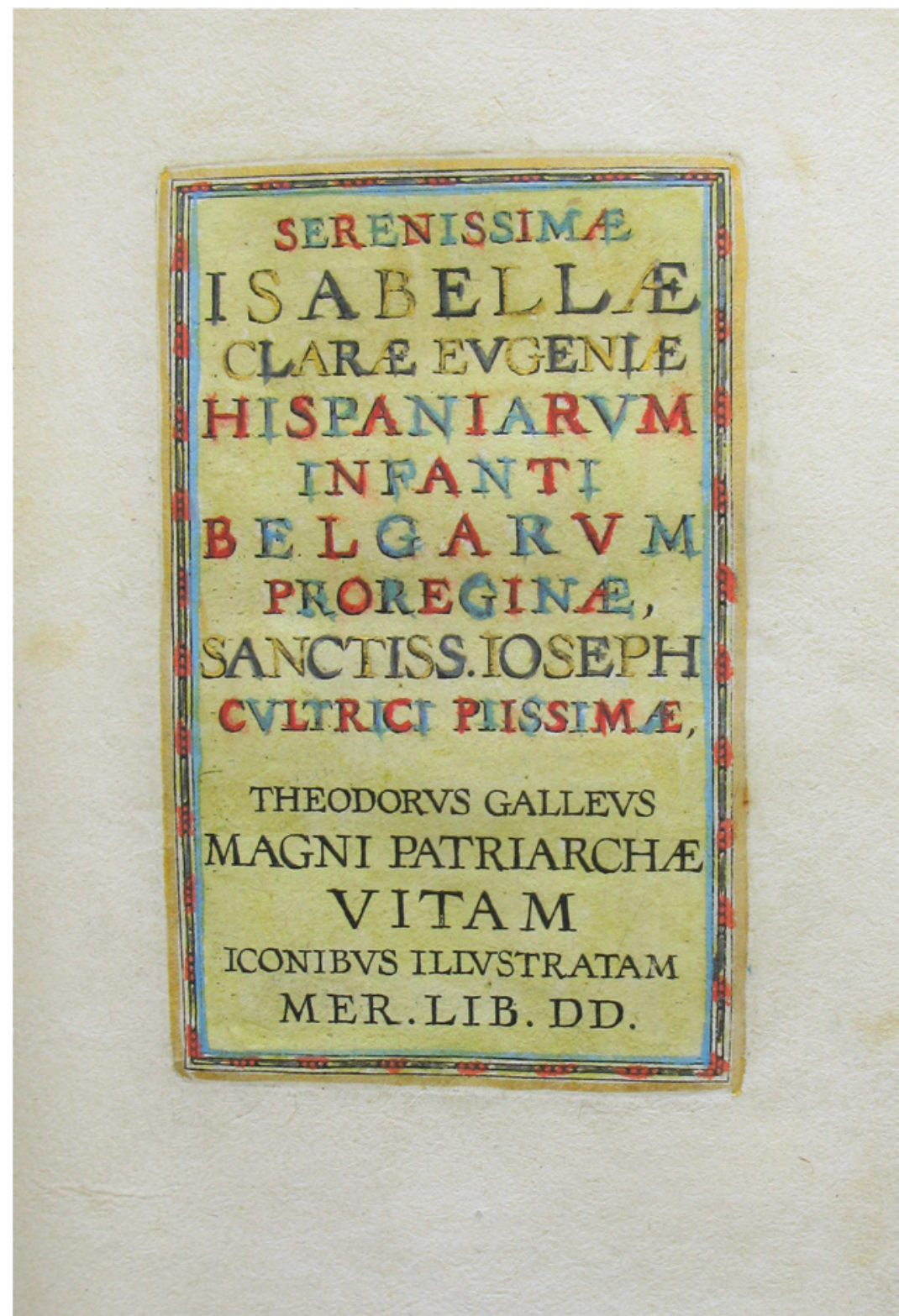

FIGURE 15.20 Theodoor Galle, "Serenissimae Isabellae Clarae Eugeniae Hispaniarum Infanti" (To the most serene Infanta of the Spaniards, Isabella Clara Eugenia), from Vita S. Joseph beatissimae Virginis sponsi patriarcharum maximi iconibus delineata ac versiculis ornata (Life of St. Joseph, Husband of the Most Blessed Virgin, Greatest of the Patriarchs, Portrayed in Images and Ornamented with Verses) (Antwerp, Theodoor Galle: ca. 16o1-1633). Engraving, 9.3 ×5.9 cm. Antwerp, Plantin Moretus Museum, м мм R 35 


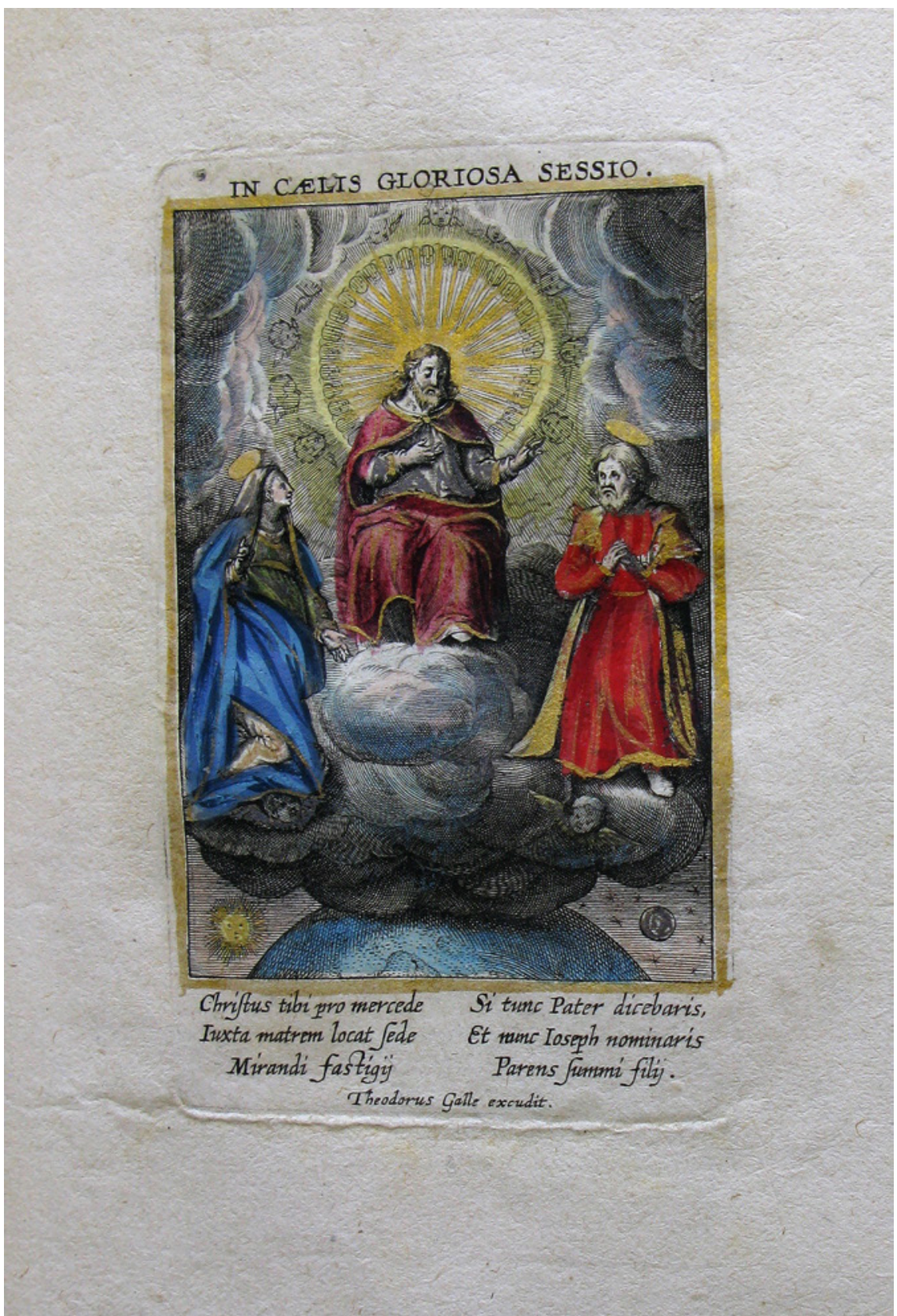

FIGURE 15.21 Theodoor Galle, "In caelis gloriosa sessio" (Glorious Seat in Heaven), from Vita S. Joseph beatissimae Virginis sponsi patriarcharum maximi iconibus delineata ac versiculis ornata (Life of St. Joseph, Husband of the Most Blessed Virgin, Greatest of the Patriarchs, Portrayed in Images and Ornamented with Verses) (Antwerp, Theodoor Galle: ca. 16o1-1633). Engraving, 8.9 ×5.3 cm. Antwerp, Plantin Moretus Museum, MPM R 35 


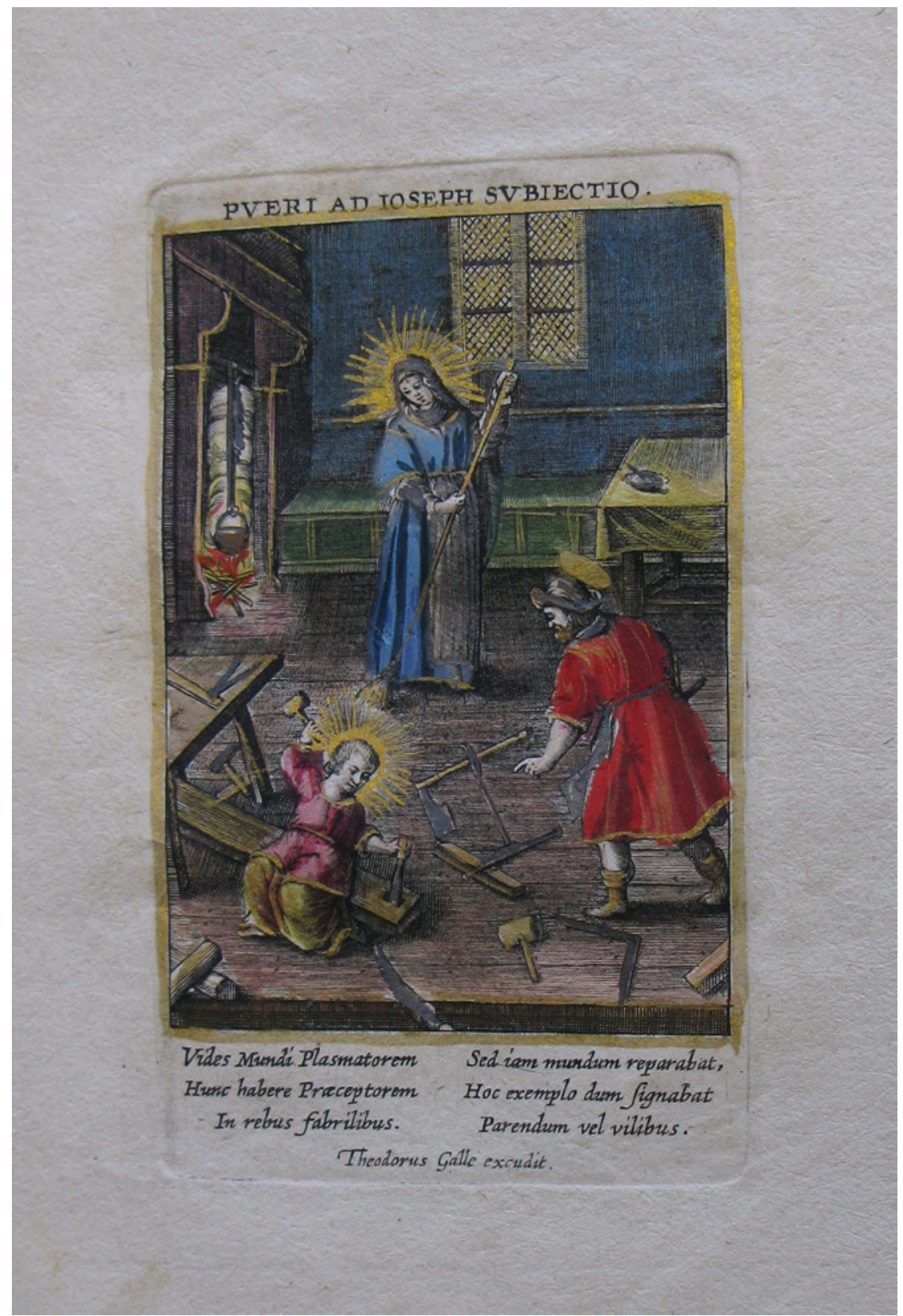

FIGURE 15.22 "Pueri ad Joseph subiectio" (Subjection of the Boy to Joseph). from Vita S. Ioseph beatissimae Virginis sponsi patriarcharum maximi iconibus delineata ac versiculis ornata (Life of St. Joseph, Husband of the Most Blessed Virgin, Greatest of the Patriarchs, Portrayed in Images and Ornamented with Verses) (Antwerp, Theodoor Galle: ca. 16o1-1633). Engraving, $8.8 \times 5.3 \mathrm{~cm}$. Antwerp, Plantin Moretus Museum, MPM R 35 


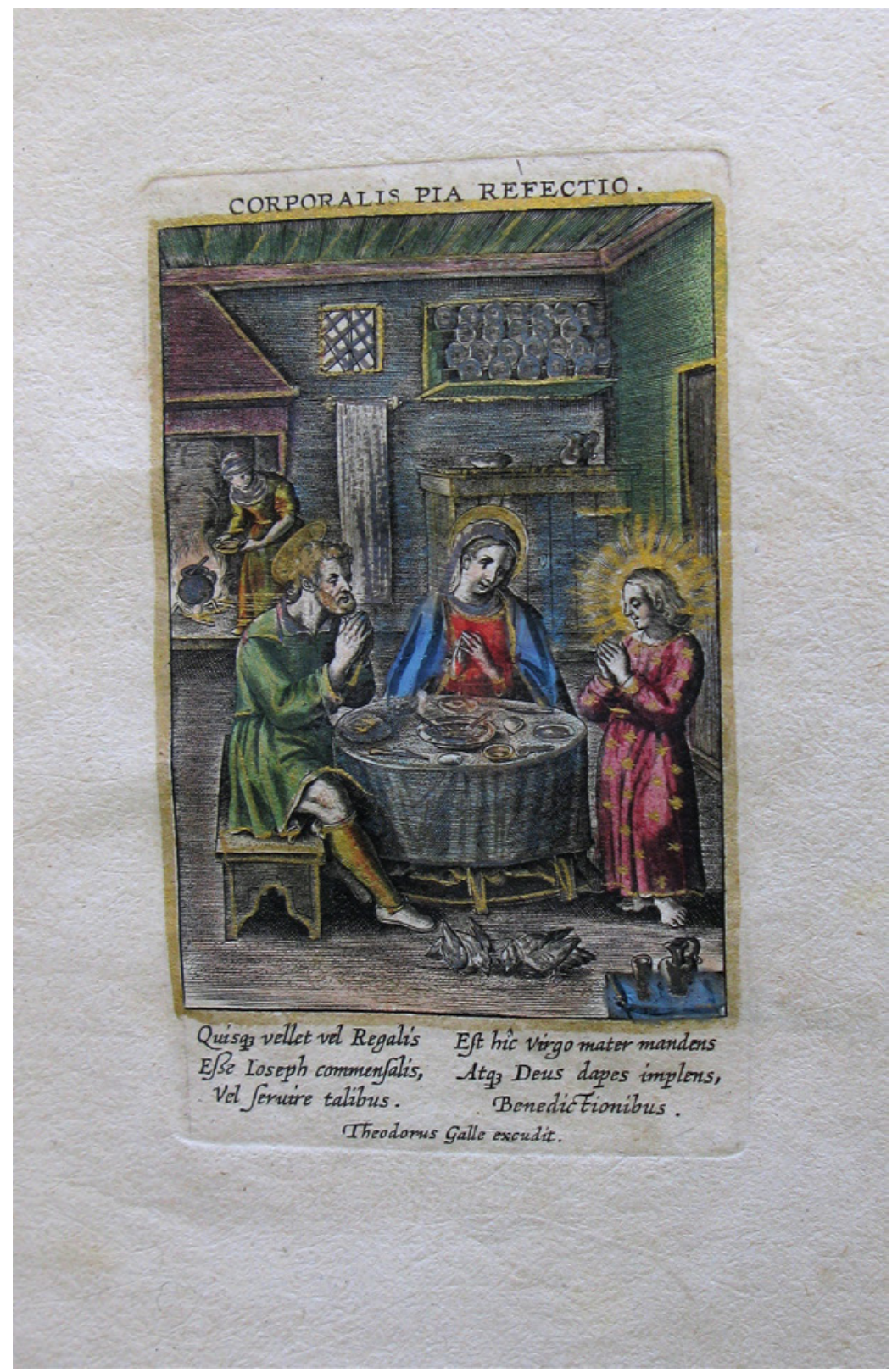

FIGURE 15.23 Theodoor Galle, "Corporalis pia refectio" (Pious Bodily Refection), from Vita S. Ioseph beatissimae Virginis sponsi patriarcharum maximi iconibus delineata ac versiculis ornata (Life of St. Joseph, Husband of the Most Blessed Virgin, Greatest of the Patriarchs, Portrayed in Images and Ornamented with Verses) (Antwerp, Theodoor Galle: ca. 1601-1633). Engraving, $8.8 \times 5.2 \mathrm{~cm}$. Antwerp, Plantin Moretus Museum, MPM R 35 


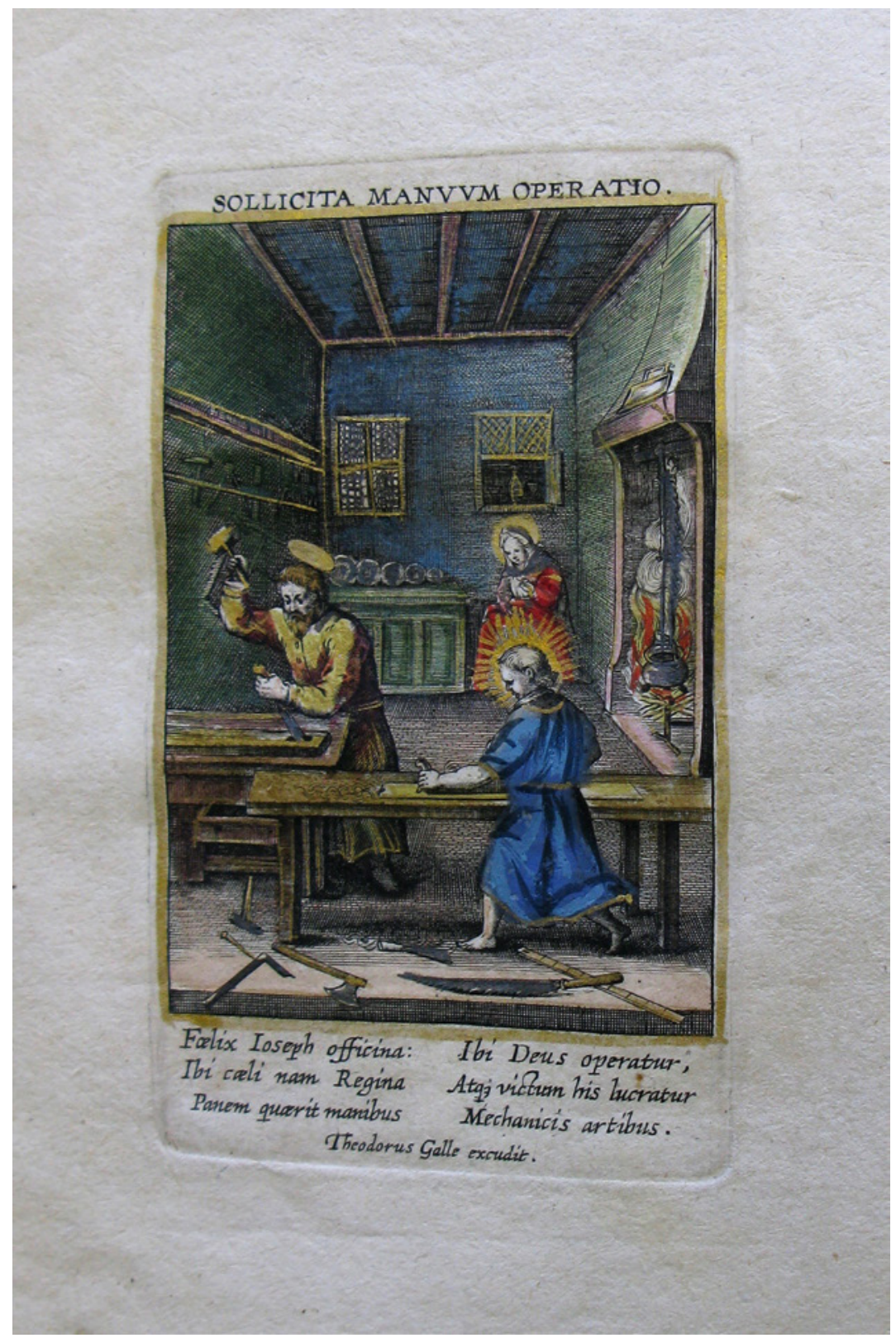

FIGURE 15.24 Theodoor Galle, "Sollicita manuum operatio" (Precise Labor of the Hands), from Vita S. Ioseph beatissimae Virginis sponsi patriarcharum maximi iconibus delineata ac versiculis ornata (Life of St.Joseph, Husband of the Most Blessed Virgin, Greatest of the Patriarchs, Portrayed in Images and Ornamented with Verses) (Antwerp, Theodoor Galle: ca. 1601-1633). Engraving, $8.8 \times 5.3 \mathrm{~cm}$. Antwerp, Plantin Moretus Museum, MPM R 35 


\section{Selected Bibliography}

Allison Peers E., Studies of the Spanish Mystics, 3 vols. (London: 1927-196o).

Baier W., "Ludophe de Saxe", in Viller M. (ed.), Dictionnaire de spiritualité ascétique et mystique: doctrine et histoire, vol. 11 (Paris: 1937-1995) cols. 1130-1138.

Baier W., Untersuchungen zu den Passionsbetrachtungen in der Vita Christi des Ludolf von Sachsen, 3 vols. (Salzburg: 1977).

Baier W. - Ruh K., "Ludolf von Sachsen", in Stammler W. - Langosch K. (eds.), Die deutsche Literatur des Mittelalters: Verfasserlexikon, vol. 5 (Berlin - Leipzig: 19772008) cols. 967-977.

Bernard M.A., s.J., "The Class of Humanities in the Ratio studiorum", Jesuit Educational Quarterly 15 (1953) 197-205.

Berteloot A. - Dijk H. van - Hlatky J. (eds.), 'Een boec dat men te Latine heet Aurea Legenda': Beiträge zur niederländischen Übersetzung der Legenda aurea (Münster et al.: 2003).

Brazeau B.J., "Emotional Rescue: Heroic Chastity and Devotional Practice in Jacopo Sannazaro's De partu Virginis", California Italian Studies 5.1 (2014) 225-246.

Calisti G., Il De partu Virginis: saggio sul poema sacro nel Rinascimento (Città del Castello: 1926).

Canisius Petrus, s.J., De Maria virgine imcomparabili, et Dei genetrice sacrosancta, libri quinque (Ingolstadt, David Satorius: 1577).

Carrasco J.A., "Fray Jerónimo Gracián de la Madre de Dios y su Summario de las excelencias del glorioso S. Joseph, esposo de la Virgen Maria o Josefina", Cahiers de Joséphologie 25 (1977) 295-322.

Carlsmith C., "Struggling toward Success: Jesuit Education in Italy, 1540-160o", History of Education Quarterly 42 (2002) 215-246.

Chorpenning J., o.s.F.s., "Introduction", in Chorpenning J., (ed.), Just Man, Husband of Mary, Guardian of Christ: An Anthology of Readings from Jerónimo Gracián's Summary of the Excellences of St. Joseph (1597) (Philadelphia, PA: 1993) 1-64.

Chorpenning J., O.s.F.s. (ed.), Joseph of Nazareth through the Centuries (Philadelphia, PA: 2011).

Chorpenning J., o.s.F.s., "St. Joseph as Guardian Angel, Artisan, and Contemplative: Christophorus Blancus's Engravings for the Summary of the Excellencies of St.Joseph (1597)", in Chorpenning (ed.),Joseph of Nazareth through the Centuries (Philadelphia, PA: 2011) 103-136.

Delarue D.E., "Concepts of Solitude in Jacobus de Voragine's Legenda aurea", in Enenkel K.A.E. - Göttler C. (eds.), Solitudo: Spaces, Places, and Times of Solitude in Late Medieval and Early Medieval Culture (Leiden - Boston: 2018) 121-139. 
Deramaix M., "La genèse du De partu Virginis de Jacopo Sannazaro et trois églogues inédites de Giles de Viterbe", Mélanges de l'École Française de Rome: Moyen Âge 102.1 (1990) 212-276.

Deramaix M., "Inepta et indecore comparatio: sacris prophana miscere: une censure ecclésiastique post-tridentine de Jacopo Sannazaro", Bulletin de l'Association Guillaume Budé (1991) 172-193.

Eustachius drama como-tragicum [....] rhetoribus gymnasii Gandensis Societatis Iesu (Ghent, Ex officina Iudoci Doomsij: 1629).

Faesen R., s.J., "The Grand Silence of St. Joseph: Devotion to St. Joseph and the Seventeenth-Century Crisis of Mysticism in the Jesuit Order", in Chorpenning J., o.s.F.s. (ed.), Joseph of Nazareth through the Centuries (Philadelphia, PA: 2011) 137-15o.

Fantazzi C. - Perosa A., "Introduzione", in Fantazzi C. - Perosa A. (eds.), Jacopo Sannazaro, De partu Virginis (Florence: 1988) vii-cxxvi.

Fleith B., Studien zur Überlieferungsgeschichte der lateinischen Legenda aurea (Brussels: 1991).

Gabriel-Kamminga M., "De Legenda aurea in druk: een vergelijkend onderzoek van de Middelnederlandse incunabelen", in Berteloot A. - Dijk H. van - Hlatky J. (eds.), 'Een boec dat men te Latine heet Aurea Legenda': Beiträge zur niederländischen Übersetzung der Legenda aurea (Münster et al.: 2003) 83-128.

Gauthier R., C.s.C., "Saint Joseph aux Pays-Bas espagnols au début du XVIIe siècle", Cahiers de Joséphologie 29 (1981) 870-896.

Goudriaan K., "Het Passionael op de drukpers", in Mulder-Bakker B. - Carasso-Kok M. (eds.), Gouden legenden: heiligenlevens en heiligenverering in de Nederlanden (Hilversum: 1997) 73-88.

Gracián Gerónimo, Summario de las excelencias del glorioso S. Ioseph, esposo de la Virgen Maria (Rome, Antonio Zannetti: 1597).

Haub R., "Petrus Canisius: Marientraktat, Mariale", in Baumstark R. (ed.), Rom in Bayern: Kunst und Spirtualität der ersten Jesuiten (Munich: 1997) 525-526.

Haub R., "Petrus Canisius: Widerlegung der Magdeburger Centurien", in Baumstark R. (ed.),RominBayern:Kunstund Spirtualität dererstenJesuiten (Munich:1997) 547-548.

Hollstein F.W.H., Etchings, Engravings, and Woodcuts, ca. 1450-1700, vol. 7 (Amsterdam: n.d.).

Hedley J.C. (ed.), Sermons of St. Bernard on Advent and Christmas, Including the Famous Treatise on the Incarnation, Called "Missus est" (London - New York et al.: 1909).

Jacobi, sive Actii Sinceri Sannazarii, De partu Virginis carmen triparititum. Die Geburt der Jungfrau, ein Gedicht in drei Gesängen, von Jacobus, oder Actius Sincerus Sannarius, lateinisch und deutsch, (Leipzig, F.L. Becker: 1826).

Jacobus de Voragine, Passionael, Winter-\& Somerstuc (Gouda, Gerard Leeu:1478-1480). 
Kennedy W., Jacopo Sannazaro and the Uses of Pastoral (Hanover: 1983).

Lazar L.G., Working in the Vineyard of the Lord:Jesuit Confraternities in Early Modern Italy (Toronto - Buffalo - London: 2005).

Lazar L.G., "Bringing God to the People: Jesuit Confraternities in Italy in the MidSixteenth Century", Confraternitas 7.1 (1996) 11-13.

Lazar L.G., "The First Jesuit Confraternities and marginalized Groups in SixteenthCentury Rome", in Terpstra N. (ed.), The Politics of Ritual Kinship: Confraternities and Social Order in Early Modern Italy (Cambridge - New York - Melbourne: 200o) 132-149.

Läken C., "Nogmaals de Legenda aurea in druk: de verhouding tussen handschriften en drukken", in Berteloot A. - Dijk H. van - Hlatky J. (eds.), 'Een boec dat men te Latine heet Aurea Legenda': Beiträge zur niederländischen Übersetzung der Legenda aurea (Münster et al.: 2003) 129-164.

Le Goff J., 'A la recherche du temps sacré':Jacques de Voragine et la 'Légende dorée' (Paris: 2011).

Le Goff J., "Preface", in Boureau A. (ed.), La Légende dorée: le système narratif de Jacques de Voragine, +1298 (Paris: 2011 ) $\mathrm{i}-$ vii.

Lorenz E., "A Carmelite in Slavery: Father Gracián, Friend of Teresa of Jesus", Mount Carmel 35 (1987) 51-63.

Ludolphus de Saxonia, Vita Christi ex evangelijs et scriptoribus orthodoxis concinnata (Paris, Vidus Thielmanni Kerver: 1536).

McGuire B.P., "Becoming a Father and a Husband: St. Joseph in Bernard of Clairvaux and Jean Gerson”, in Chorpenning J., O.s.F.s. (ed.), Joseph of Nazareth through the Centuries (Philadelphia, PA: 2011) 49-61.

Melion W.S., 'Quae lecta Canisius offert et spectata diu': The Pictorial Images in Petrus Canisius's De Maria Virgine of 1577", in Melion W.S. - Wandel L.P. (eds.), Early Modern Eyes: Discourses of Vision, 1500-1800 (Leiden - Boston: 2009) 207-266.

Melion W.S., The Meditative Art: Studies in the Northern Devotional Print, 1550-1625 (Philadelphia, PA: 2009) 189-239.

Monti S., "La dedica del De partu Virginis di Iacopo Sannazaro nelle vicende della suo genesi", Aevum 73.3 (2001) 629-640.

Moriones I., "Jérome de la Mère de Dieu", in Guibert J. de, s.J. - Viller M. - Cavallera F. (eds.), Dictionnaire de spiritualité, vol. 8 (Paris: 1974) cols. 920-928.

Nazzaro A.V., "Il De partu Virginis del Sannazaro come poema parafrastico", in Sabbatino P. (ed.), Iacopo Sannazaro: la cultura napolitana nell'Europa del Rinascimento (convegno internazionale de studi, Napoli 27-28 marzo 2006) (Florence: 2009) 167-209.

O'Malley J.W., s.J., "Some Distinctive Characteristics of Jesuit Spirituality in the Sixteenth Century", in O'Malley J.W., S.J., Saints or Devils Incarnate? Studies in Jesuit History (Leiden - Boston: 2013) 165-180. 
Olszewsky H.-J., "Ludolf von Sachsen”, in Bautz F.W. - Bautz T. (eds.), Biographischbibliographisches Kirchenlexikon, vol. 5 (Hamm - Herzberg - Nordhausen: 1975) cols. $312-314$.

Pacho E., "Jerónimo Gracián de la Madre de Dios: vida y obra", in Pacho E. (ed.), El Padre Gracián: Discípulo, amigo, provincial de Santa Teresa (Burgos: 1984) 7-57.

Prandi S., "Arcadia sacra: l'ultimo sogno dell'umanesimo", in Prandi S. (ed.), Jacopo Sannazaro, Il parte della Vergine volgarizzamento di Giovanni Giolito de' Ferrari (Rome: 2001) 7-57.

Quint D., Origin and Originality in Renaissance Literature: Versions of the Source (New Haven - London: 1983).

Ratio atque institutio studiorum Societatis Iesu, auctoritate septimae congregationis generalis aucta (Antwerp, Apud Ioannem Meursium: 1635).

Ruyven-Zeman S. van - Leesberg M. (comps.), Hollstein's Dutch and Flemish Etchings, Engravings, and Woodcuts, 1450-1700, vol. 61: The Wierix Family, Part 3 (Rotterdam: 2003).

Shore P., "The Vita Christi of Ludolph of Saxony and its Influence on the Spiritual Exercises of Ignatius of Loyola", Studies in the Spirituality of Jesuits 30.1 (1998) 1-17.

Solà F. de P., s.J., "San José en Francisco Suárez", Cahiers de Joséphologies 25 (1977) 237-251.

Solà F. de P., s.J., "Josefología del P. Alonso Ezquerra, S.J. (1555-1637)", Cahiers de Joséphologie 29 (1981) 210-237.

Williams-Krapp W., "Mijn wille en es niet jegen Gods geloeve ocht jegen de heilge kerke te doene' - Zur Rezeption der Legenda aurea im deutsch/niederländischen Raum”, in Berteloot A. - Dijk H. van - Hlatky J. (eds.), 'Een boec dat men te Latine heet Aurea Legenda': Beiträge zur niederländischen Übersetzung der Legenda aurea (Münster et al.: 2003) 9-17. 